\title{
THE MARICOPAS
}

An Identification from Documentary Sources

THE UNIVERSITY OF

ARIZONA PRESS

TUCSON

1963 


\section{THE MARICOPAS}

An Identification From Documentary Sources

\section{PAUL H. EZELL}

NUMBER 6

\section{ANTHROPOLOGICAL PAPERS \\ OF THE UNIVERSITY OF ARIZONA}

THE UNIVERSITY OF ARIZONA PRESS

TUCSON 1963 
Copyright (C) 1963

The Board of Regents of the Universities and State College of Arizona. All rights reserved.

L. C. Card Catalog No. 63-11980 


\section{THE MARICOPAS}

This study is an outcome of an archaeological survey conducted in December, 1957, for the National Park Service by Albert H. Schroeder and myself. Since historical data for the area include information on Indian occupants, a reconstruction of the history of the area becomes a study in ethnohistory as well as archaeology. The report on the surface archaeology has been prepared by Schroeder (1961) for separate publication.

In attempting to distinguish ethnic identities among populations noted in the historical record as having been present in the past in that portion of the Gila Valley contained within the presentday Painted Rocks Reservoir area in Arizona, it is not possible to limit the discussion to that area alone. While the landmarks - the Great Bend of the Gila, the Painted Rocks Mountains, and consequent changes in the course of the river - are such that one can usually be confident in the identification of pertinent passages in the diaries of travelers, the reservoir area is, after all, an arbitrary and artificial segment of a larger geopolitical unit. Since groups from outside the region are known to have entered it for varying lengths of time, the occupants of the area must be identified in terms of the larger socio-political setting - the populations of the lower Gila and Colorado rivers and their environs. In the main, the human geography of this portion of the southwestern United States, which may be called the Gila-Colorado area, is rather well understood in broad outline and in some detail. That portion of the Gila River from the junction of the Salt River on the east to the vicinity of the hot springs identified early in the historical record as Agua Caliente on the west, being the eastern section of what is commonly identified as the lower Gila, is one, however, where ethnic composition has not been worked out in the detail necessary for reconstruction of the ethnohistory of a segment of the area.

For the first two centuries or so of the historical record, the lower Gila River in southwestern Arizona marked a limit of exploration - the northwestern frontier of New Spain and, afterward, Mexico. For a time after United States occupation of the area, it continued to be essentially a frontier, i.e., still-to-be-settled region. Throughout the entire period, however, it was rather paradoxically part of the overland route to California, so that written records regarding the area continued to be made at intervals despite the lack of nonIndian settlements in it until late in the nineteenth century. Political events in such distant places as Mexico City, Madrid, London, Paris, and Moscow operated to give the lower Gila a greater importance than it might otherwise have acquired. For one thing, the region was important as the only route to California that was free from menaces of pirates, thirst, and hostile Indians, and for another, it simultaneously constituted, in the eyes of the Spaniards and Mexicans, part of a defense perimeter against foreign encroachments. The vagaries of international relationships influenced travel along the river so that the historical record came to be one of segments separated from each other by complete lack of documentation. This circumstance has been used as framework within which to trace the Indian occupation of that section of the river between the southern part of the bend of the Gila and the Painted Rocks Mountains some fifteen or more miles downstream - that portion which lies within the Painted Rocks Reservoir area - as well as certain adjacent areas.

Although the Oñate reports included a hearsay statement about the population of the lower Gila in the report of the 1604 expedition down the Col- 
orado River, no member of his party traveled the Gila itself. In any case, the statements probably had reference to the Gila below the Painted Rocks Mountains. Kino's report of 1694 (1948: I: 127-29) regarding the population of the lower Gila and Colorado rivers, including as it did statements obtained on the middle Gila in the vicinity of the Casa Grande ruins from people who were in contact with those along the lower river, constitutes the earliest acceptable reference of the first segment of the documented record. This first period - the Spanish period - can be divided into two parts. The earlier of the two is the Jesuit period, after the religious organization then active in the exploration of the area. This era was terminated by the expulsion of the Jesuits from the New World in 1767. The later part may be called the Franeiscan since this order replaced the Jesuits in northwestern New Spain. A hiatus from about 1799 to about 1823 separates the Spanish from the following Mexican period which can be viewed as ending with the U. S. Army expedition under General Kearny in 1846. This ushered in the American period, although political control of the area north of the river did not pass to the United States until 1848 and south of the river until 1854 .

Spier (1933:1-47) and Schrocder (1952: 160-65) have previously provided reconstructions of ethnic identities and distributions for the lower Gila, based on published sources then available. Since that time additional sources have been published and even more unpublished documentary sources have become available. In the light of this additional data, recapitulation and reexamination seem advisable.

For the Jesuit period there are firsthand accounts by Kino (1948:I:196-97) and Manje (1954: 119-22) of their journey through the area in 1699 , by Kino (1948:I:246-48) for his trip in 1700, and Sedelmayr's accounts (MSS 1744, 1746, 1749 ) of his journeys in 1743, 1744, and 1749. Kino's map (1948:frontispiece) of 1705 likewise may stand as a primary source inasmuch as that portion of it showing the Painted Rocks Reservoir area presumably was prepared on the basis of his two trips through it. While an additional body of statements pertaining to the area also exists, these must be considered as hearsay evidence in that they are statements made or conclusions drawn about the area, not reports of observations made at firsthand. In this latter group are included the statements by Kino (1948:I:19$28,186-87$ ) for 1694 and 1698 , by Polici (1697 MS) for 1697, by Velarde (in Manje 1954:227, $241,246,265$ ) in 1716 , the Del'Isle map of 1722 , statements by Decorme (1941:427-28) in 1753 and 1755. and by Nentuig (Rudo Ensayo 1951:3, 16-17) in 1757. Of these, the Kino entries, reporting specific occurrences as they do, possess the greatest reliability and provide the most information; the rest are either uninformative or demonstrably inaccurate upon occasion. The Kino map of 1701 (Bancroft 1889:499) is not considered reliable because the order of occurrence of the place names on it is not in agreement with the order in which they had been reported previously in the diaries. The source of information for the Del'Isle map is unknown.

The most detailed information for any portion of the historical record of the area is provided by the accounts of travelers during the first decade of the Franciscan segment. Beginning with Garcés' diary ( $1770 \mathrm{MS}$ ) of his 1770 trip through a portion of the section of the river concerned, there are the diaries of Anza (Bolton 1930:II:122-25), Díaz (Bolton 1930: II:300-302), and Garcés (Bolton 1930:II:375-77, 387-88) for the first Anza expedition to California in 1774, of Anza (Bolton 1930: III: 23-31), Font (Bolton 1930: III:21922:IV:51-59), and Garcés (1900:I) for 1775 for the second Anza expedition, and of Garcés (1900:II) for 1776 when he diverged from that expedition. In addition, there are Garcés' papers (MSS 1775, 1776) from the Querétaro Archives, set down after his return there in 1776 and suggesting that he had been engaged in the preparation of a comprehensive report on all of his explorations from the time he went to Sonora until that year. Font's map of 1777 (Bancroft 1889:393) and Garcés' map of 1776 (Palou 1926:IV:facing 88) are so generalized that they are of little use for specific locations or identifications when compared with the diaries. After the Anza expeditions, reports of travel through 


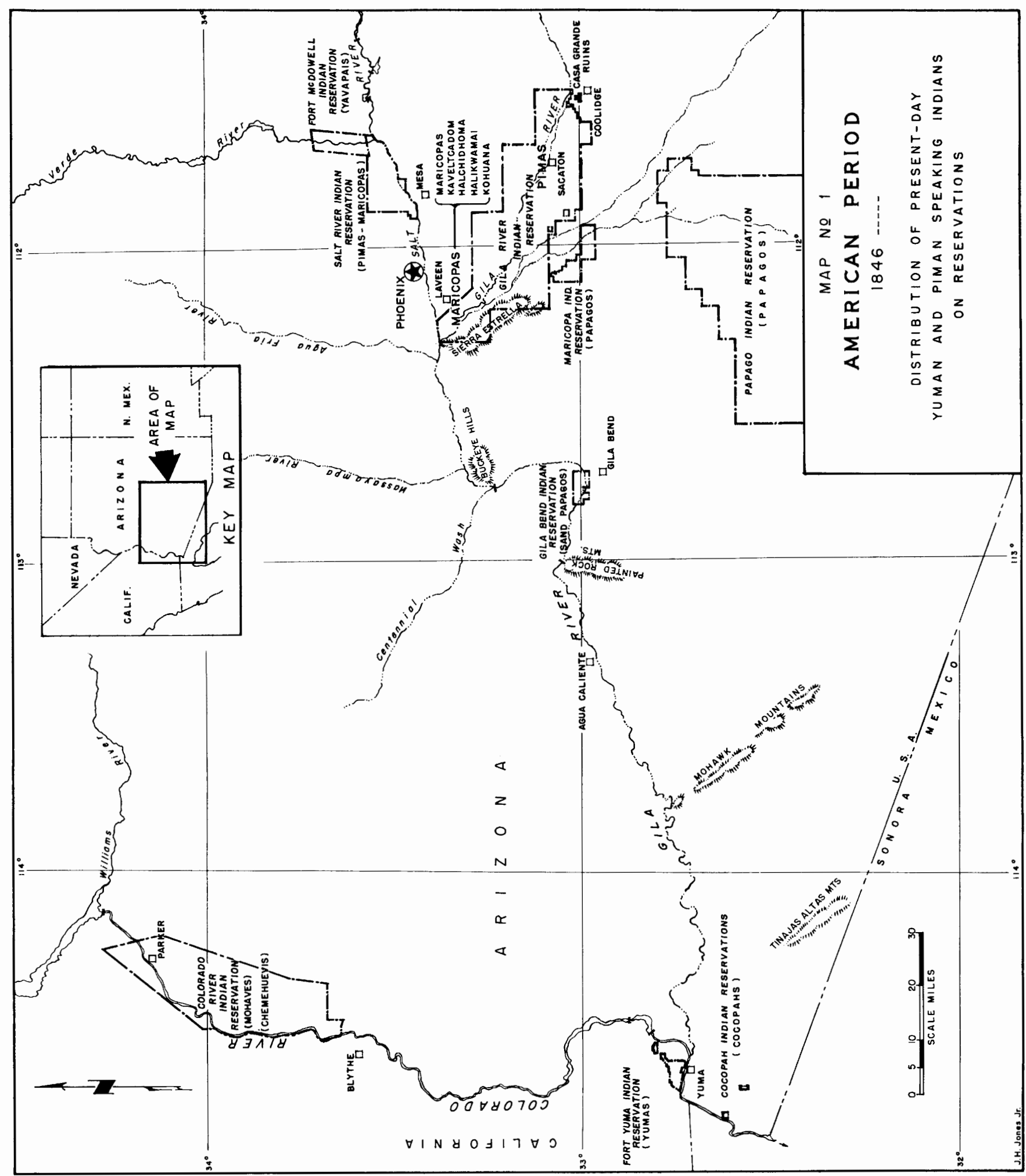


the area fall off sharply in number and usefulness. Rivera presumably traveled along the lower Gila in 1781 (Croix 1941:237). I have not been able to inspect his letter to which Croix referred to see what, if anything, he may have written concerning the people in the area. The account of the relief expedition after the destruction of the Colorado mission later that year contains information on locations and sizes of the westermost settlements in the area with which we are concerned. Of the secondary sources bearing on the area, Arguiello's account (1797 MS) of his stay at the Gila-Colorado junction in 1779 contains statements regarding the Gila which were obtained from others. Arricivita (1792), writing in 1792, and Bringas, writing in 1794 and 1795, both evidently had access to the papers of Garcés, Font, and Díaz in Querétaro. The former provides nothing of his own; Bringas' oration (1819) over the remains of Díaz and Garcés includes some statements which could only have been obtained from Garcés, either through conversation with him or from his writings. The map of Bringas' 1795 journey to the Gila (Ezell 1956) is remarkably like Font's map insofar as the lower Gila is concerned, although some of the information regarding peoples on the lower Gila could as well represent statements made to him by the Gila Pimas when he visited them. Cortez' Memoir (1799 MS) is obviously a compilation from already existing sources so far as this whole area is concerned.

The Mexican period was ushered in by Mexican independence from Spain in 1821, but was not marked by the same initial activity in exploration as were the two preceding segments of the documentary record. Although Fray Felix Caballero made two trips between his mission of Santa Catalina in Baja California and Tucson, the records of those journeys are available to us only insofar as they are cited in secondary works (Beattie 1933:54-60; Richman 1911:470). Internal evidence indicates that only Caballero's return crossing, when he was accompanied by Romero, was by way of the Gila River. Romero returned to Tucson via the Gila in 1825, having failed to make connections with Figueróa, who had traveled down the Gila to the Colorado in the expectation of meeting him but had returned to Sonora through Papaguería before Romero arrived at the Colorado (Figueróa 1825 MS). Unfortunately, I do not have available the original reports of Caballero and Romero - only studies in which these documents have been used as source material by writers having different interests. An anonymous report that a Fray Núñez also traveled the Gila in 1825 remains without confirmation. For the next twenty years, from 1826 to 1846 , accounts dealing with the area refer almost entirely to American trappers and traders, most of whom did not leave firsthand accounts. St. Vrain and Bill Williams took a party of trappers down the Gila in 1826 (Cleland 1950:251-54); Robidaux, Ewing Young, the Patties, Yount, "Pegleg" Smith, Sublette, Boggs and Anderson, with an unkown number of companions made a total of at least six trips through the area during the winters of 1826-27 and 1827-28 (Cleland 1950:88, 179, 180-82, 212-15; Pattie 1905; Emory 1848:89; Johnston 1848:603); Young and Carson in 1830 (Cleland 1950:234; Carson 1926:18-20); Jackson and Young in 1831-32 (Denhardt 1941:342; Cleland 1950:234-37), and Young in 1934-35 (Cleland 1950:240-41) all made trips through the area. None of them, including Pattie's lengthy but erratic account, make more than passing reference to the lower Gila, and the entire collection does not provide as much information as any one of the Spanish diaries. The two remaining collections of documentary sources, those of the Kearny expedition of 1846 (Emory 1848) and the Graham expedition of 1848 (Couts 1848 MS) being once more accounts of explorations, are very informative and foreshadow the voluminous reporting of the Forty-Niners.

There is a reliable record of twenty-three journeys through the area, between 1699 , when Kino and Manje made the first recorded journey along this stretch of the Gila, and 1849, when the goldseekers heading for California began to travel it. In view of the possibility of having articles of European cultural origin by which to date archaeological sites, it should be noted that few of those expeditions were of such nature as to be likely 
that much of their goods fell into the hands of the Indians. With very few exceptions the parties which traveled the river were either small and lightly equipped or very careful of their possessions. Sonora itself was always too ill-supplied with goods to admit either of plentifully supplied expeditions or of largesse to Indians not under mission or military control. Dadivas (trinkets) are mentioned occasionally. According to Arthur Woodward (personal communication) these consisted usually of such cheap and easily portable items as ribbons, rarely a few beads, small crucifixes, or medallions; tobacco and chocolate are also occasionally noted as items given to Indians. Generally the objects which the Indians obtained were perishable and not such as are likely to occur in the archaeological context. The outstanding exception was the second Anza expedition to California. Not only was it large and well equipped with supplies for the expedition itself and the settlers bound for California, but there were carried, in addition to the suit of clothes for Palma - the Yuma leader - and tobacco, a large quantity of beads, mostly red, to be given to Indians along the route (Bolton 1930:I:224). For example, 500 persons were noted as being so honored at the village of Uparsoytac (Bolton 1930:III:25). That generosity of distribution of goods was governed by circumstances, however, is indicated by the fuss raised when an Indian made off with Anza's china pot (Bolton 1930:IV:50).

On the whole, it is unlikely that sites along the routes of the expeditions in the Painted Rocks Reservoir area can be identified simply by the presence of objects of European or Mexican manufacture. Instead we must rely on the internal evidence of the various travelers' accounts, which is summarized in Figure 1. This evidence consists of topographic features, place names, distances between points, and described locations. Examples of topographic features which were unmistakable and consistent in occurrence were the hot springs - Agua Caliente - the mountains causing the northward divergence of the river - Painted Rocks Mountains - and the great bend in the Gila. Some place names, by the consistency of their occurrence in connection with a particular locality, made possible continuity between two - or more - periods of time. Keeping in mind the variation of the league as reported by the man on foot or horseback, the distances given between recognizable topographic features are consistent through time. Described locations are such as to make identifiable through time such elements as the ford consistently used just downstream from the Painted Rocks Mountains and the associated pasturage, the settlement consistently described as located at the east foot of those same mountains, and the comparatively large population dispersed in either one large or several smaller settlements around the great bend.

The principal source of confusion about the ethnohistory of the lower Gila arises out of uncertainty regarding the ethnic identifications of three names - Opa, Cocomaricopa, and Maricopa. The names of other peoples are also associated with the ethnohistory of the lower Gila, including the reservoir area, but constitute less of a problem. It was found that clarification of the Opa-Cocomaricopa-Maricopa problem followed more easily upon discussion of the other group names.

The earliest records of European contact with peoples living along the lower Gila are those of the Oñate expedition of 1604-05. A ranchería of people, differing in language, dress, and behavior from the Yuman populations along the Colorado was found on the Gila River at its junction with the Colorado River. Those people, the name of which was variously rendered as Ozara (Zarate Salmerón 1856:34-35), Oseca, Osera, and Ocara (Escobar in Hammond and Rey 1953:1020), have been identified as a branch of the Piman peoples more commonly known as Areneños or Sand Papagos (Ezell 1955:371-72) whose homeland was the desert between the lower Gila and the Gulf of California.

Two terms, "Pima" and, less frequently, "Pagago" also occur in connection with the lower Gila. Today these terms represent administrative convenience, although members of the same family may be identified as "Pima" or "Papago" depending on where they live. It is necessary to avoid this reification when interpreting those two names in the historical record, where it is apparent that 


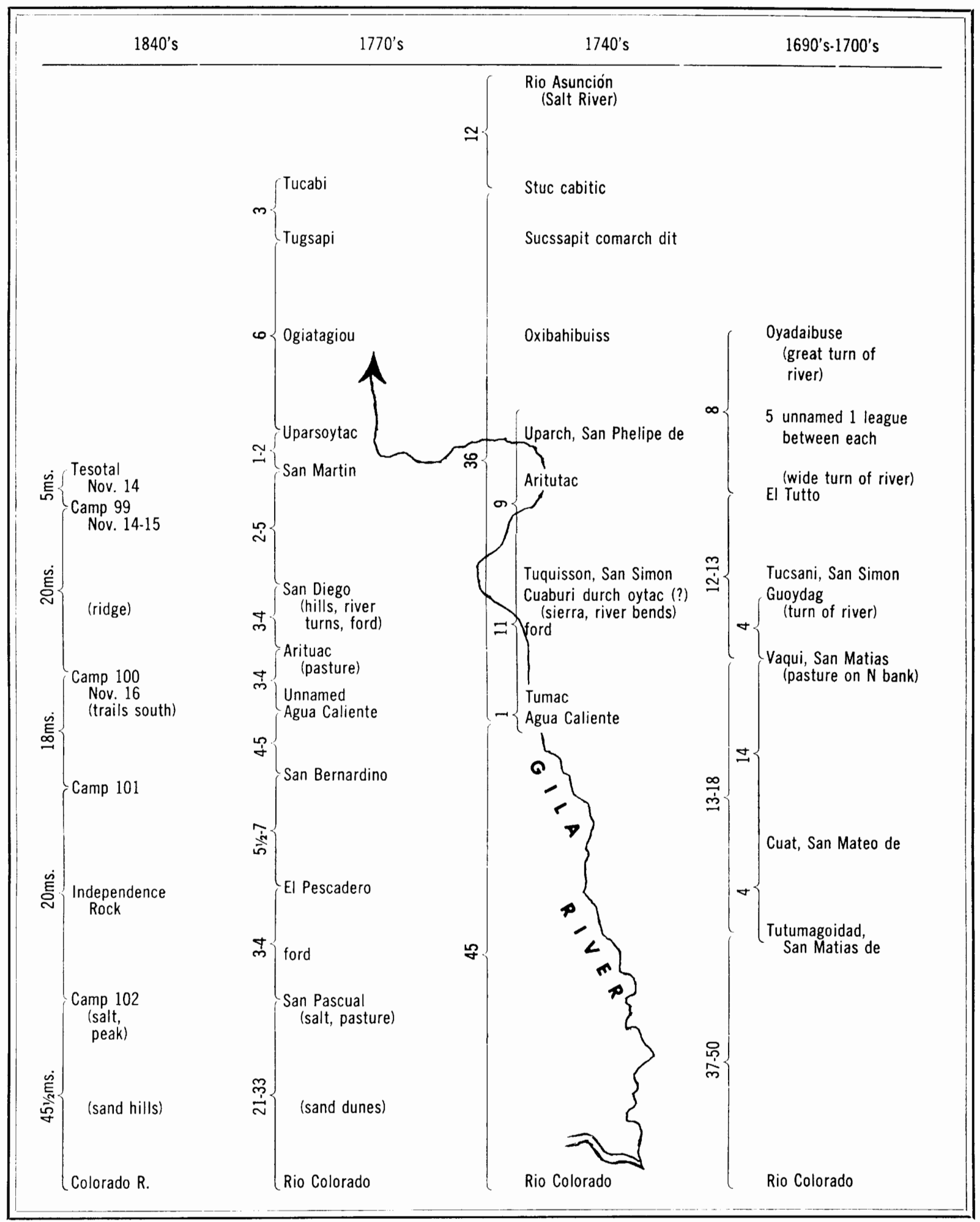

Figure 1: Settlements along the lower Gila, 1690's-1840's. Distances given in leagues, except as noted. Sources: Manje 1954; Bolton 1930:II-IV; Emory 1848; Garcés 1900:II, MSS 1770, 1776; Sedelmayr MSS 1746, 1749, 1751; Kino 1948. 


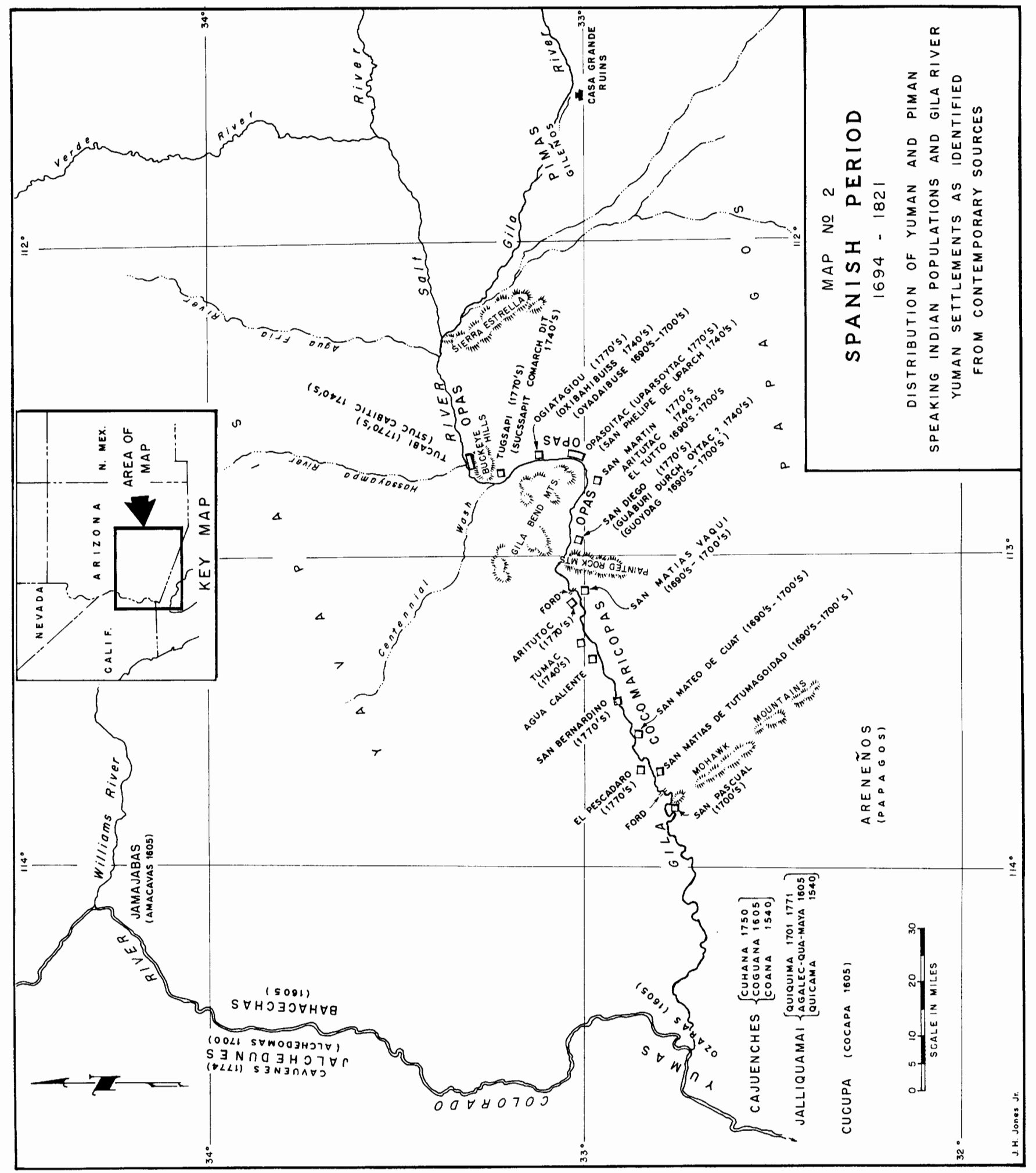


their application was much less dependable. Garcés (1771 MS) identified as "Pimas" the people now known as "Sand Papagos" or Areneños, whereas Anza and Díaz (Bolton 1930:II:17-30, 260-62) referred to them as Papagos. On the other hand, a Mexican writer of 1849 referred to the Gila Pimas as the "Papagos gileños" (Anonymous 1849 MS), and American writers of the same period identified the Piman-speaking peoples now known as Papagos - in the Santa Cruz Valley as "Pimas" (Goulding 1849 MS). Until after the middle of the nineteenth century the general practice was to use the term "Pima" to identify individuals speaking a dialect of the Piman language, wherever found in northwestern Mexico, and to restrict the use of the term "Papago" (or some variation thereof) to that portion of the "Pimas" inhabiting the northwestern desert instead of the river valleys for whom planting was of necessity a supplement to food collecting rather than the base of their subsistence. Consequently, references to "Pimas" among the Yuman-speaking inhabitants of the lower Gila and adjacent portions of the Colorado cannot be taken unquestionably to identify Gila Pimas.

A further complication is the presence in the literature of another name used to refer to a Piman-speaking group. While the Kwahatk (Papago Kohatk) are usually thought of as living in Papaguería away from the river but forming a separate population intergrading culturally as well as geographically between the "true" Papagos and the Gila Pimas, there is evidence that they, too, lived along the Gila upon occasion. Font was the first to experience indecision as to their "proper" designation, since he referred to them as "Papago Pimas" in one entry and in another identified them as "Papagos, who at times live on the Gila River" (Bolton 1930:IV:30,33). Hints of the use of the term, however, earlier appear in the documents. Manje (1954:120) identified the second village below the Painted Rocks Mountains as San Mateo de Cuat, which is closer to the Pima than the Papago pronunciation. Sedelmayr (1746 MS) noted a place name, Cohatc, as the settlement next upstream from San Phelipe de Uparch, which would place it just above the bend on the north-south reach of the Gila. Anza noted that the population of Opasoytac (near modern Gila Bend) was increased in the summer of 1774 by "some Papagos or Pimas who have deserted their country on account of the great drought and the still greater famine which is experienced in it" (Bolton 1930:II:124).

Evidence for the conclusion that some of the references denote in fact members of the group commonly known as "Sand Papagos" has been assembled elsewhere (Childs and Dobyns 1954:2731; Ezell 1955:370-72). Since a people at least partially dependent upon planting are the more liable to be affected as Anza described, and since the Sand Papagos were hunters and gatherers culturally adapted to an ecology where almost complete lack of rain is usual, the Piman component of the Opasoytac population that year was probably the Kwahatk. In attempting to determine whether "Pimas" in the Yuman settlement along the lower Gila and Colorado during the Hispanic period should be taken to mean Kwahatk or Sand Papago, one might be guided by the relationships described as obtaining between the Yuman peoples of the two rivers. In view of the hostilityfriendship patterns (e.g. Garcés 1900:II:449-53), it is most probable that those Piman individuals in settlements below Agua Caliente were Sand Papagos, while those above were Kwahatk or Gila Pima.

One of the group-identifying names associated with the area, "Yuma," is happily devoid of ambiguity. Rarely was any other name given in the documents as referring to the people identified by this term - "Cutchana" by Garcés (Bolton 1930:II:382) and "Cuchan" by Couts (1848 MS) are some - nor has the name "Yuma" been found applied to other groups. It is interesting to note that no name identifiable as referring to this group appears in the 1605-06 records of the Onate expedition. In view of the succeeding history of Yuma belligerency it seems probable that the Oñate party did not meet the Yumas because they were the people inhabiting the west bank of the Colorado below the Gila junction at that time and feared by the people of the east bank as hostile to them (Zarate Salmerón 1856:36; Ham- 
mond and Rey 1953:1022). By the end of the century, however, the Yumas had established themselves around the junction of the rivers. The first certain reported European contact with them was that of Kino and Manje in 1699 at a site on the Gila east of the Gila Mountains some three to five miles west of the present town of Wellton where they found a large Yuma ranchería which they named San Pedro (Kino 1948:I:194; Manje 1954:11315 ). As a function of the dynamics of riverain occupation, the geopolitical area of the Yumas thus included the valley of the Gila upstream from the Colorado to the distance that interaction could be maintained between the Yuma settlements on both rivers. That is, for a people with a handicraft technology and planting as the economic base, dwelling along a river and dependent on it for water to irrigate fields (either by flooding or ditches), the river constitutes the core of their territory rather than a boundary or perimeter. Such societies exploit the territority out from the core for resources not obtainable from the planting area, such as stone for tools, clay for pottery, game, plant foods, and plant material for manufactures. That portion of the Gila contiguous to the Colorado thus constituted part of the Colorado area of Yuma exploitation rather than the Gila area of Cocomaricopa exploitation, which did not extend down the Gila to its junction with the Colorado. Properly speaking, therefore, the Yumas cannot be said to have been part of the geopolitical unit signified by the term lower Gila, since their historic associations have been primarily with the lower Colorado. The principal importance of the Yumas for the culture history of the lower Gila lies in the hostility obtaining, except for short-lived truces, between them and the inhabitants of the Gila, and the friendship obtaining between them and the Piman Areneños. As a consequence of this hostility-friendship pattern, the transculturative effects on the latter (Childs and Dobyns 1954:29; Ezell 1955:370-71) provided a means by which cultural items from the Yumas could occur in the territory of their enemies along the lower Gila, as the Areneños communicated with linguistic congeners in the area.

Another term occurring in the documents re- lating to the lower Gila is "Coloradoans," evidently referring to individuals whom the Spaniards identified as resident along the Colorado River and only visiting the people living along the Gila. As to which one was meant of the several groups living in the valley of the Colorado there is less certainty, although the known nature of the relationships between the various groups occupying the lower Gila and Colorado valleys admits of a reasonable inference. Owing to the hostility obtaining between the Yumas and the occupants of the Gila it is possible to eliminate the Yumas and, because of their alliance with the latter, the Mohaves. Of those remaining, the most likely candidates were the Halchidhoma. This group was reported by the Oñate party as the first group met - as the Alebdoma, on the east bank of the Colorado - below the confluence of the Gila in 1605 (Zarate Salmerón 1856:35; Hammond and Rey 1953:1021), where they apparently continued until 1699 when Kino (1948:I:195) noted their existence. By the next year, however, when Kino (1948:I:252) returned, they had evidently moved upriver where they were reported at intervals until 1827-29, at which time they left the Colorado to settle ultimately on the Gila (Spier 1933:14). During the period 1700-1827 repeated notations occur in the historical record of communication between the Halchidhoma and the peoples of the lower Gila, hence the conclusion that "Coloradoans" referred to that group.

The evident relationship, one to the other, of the terms "Opa," "Cocomaricopa," and "Maricopa," the cultural similarity of populations so designated by the diarists, and projection of current concept into the past have operated to obscure the historical significance of those names. At the outset it should be noted that the word "Maricopa" as the name for all the Yuman-speaking peoples of the Gila and Salt valleys did not appear in any document until 1846 - in the records of the Kearny expedition. It is not to be found in any of the documents for the Spanish and Mexican periods. Its use as an all-inclusive designation for the Yuman-speaking population of the Salt and Gila valleys (e.g., Kino 1948:I:194 fn.258), however, has been a factor in creating 
the impression that those inhabitants constituted a single ethnic entity, and that one or another of the terms could be, as in fact each has been, used to identify that larger group without due regard for time level. Tracing the application of the terms in chronological order of use, however, it can be seen that such has not always been the case, as has already been noted by Spier (1933:25-37) and Schroeder (1952:160-65). Since "Maricopa" became common usage only after the Hispanic period it can be excluded from consideration for the moment, and the problem defined in terms of the significance of "Opa" and "Cocomaricopa."

The first known appearance of the names Opa and Cocomaricopa was in 1694 when Kino (1948:I:128) was told by the Gila Pimas that people designated by those terms lived farther down the Gila and on the Colorado, and that they were friendly but spoke a language different from that of the Pimas. Kino evidently saw some of them among the Pimas, since he indicated that some were present at that meeting (1948:I:129). In 1698 he described as from his own observation differences in physique, dress, and language which set them off from the Pimas (1948:I:18687 ) when he noted that some of them had come to see him when he was again visiting in one of the Pima towns, although he made no distinction between Opa and Cocomaricopa. In 1699 he listed Opas, Cocomaricopas, Pimas, and Yumas as the people gathered to see him at San Pedro, and noted that the language of the Cocomaricopas was that spoken by the Opas and the Yumas (1948:I:194-95). Oyuela listed "captains" of the "Yuma and Opa and Cocomaricopa nations, who live on the Rio Grande [Gila] and the Rio Colorado, sixty and eighty leagues distant" among those who came to meet him and Kino at Sonoyta in 1706 (Kino 1948:II:210). On the other hand, Kino used only the term Cocomaricopa to identify the Yuman-speaking peoples along the lower Gila when he passed through in 1700 (1948:II:246), and no other Jesuit-period explorer used the term Opa except in combination with a prefix. Furthermore, Kino never associated the name Opa with a geographical location other than in combination with the Cocomaricopas. The rest of the Jesuits similarly made little of differences of names for populations speaking mutually intelligible languages and sharing the majority of other culture elements. Sedelmayr had the most extensive acquaintance of all the Jesuit explorers with the Yuman-speaking peoples of the Gila and Colorado rivers, visiting them in 1743, 1744 and 1749, yet was unable to discern any bases for identifying them as other than one people, Cocomaricopas (1746 MS). The Yumas, he wrote, had been reported as a separate nation only because of the enmity between them and the Cocomaricopas, and he identified people on the Colorado later known to have been the Halchidhoma only as another group of Cocomaricopas having kinship ties with those of the Gila. He did vary his rendition of the term by recording it as Cocomaric-opa a number of times (1749 MS; 1751 MS), as did Middendorff $(1957: 3,4)$ who wrote it Cocomaric-Oopa.

It is during the succeeding Franciscan period that the two names occur in diaries and reports most frequently and with the appearance of having some real difference of application. After 1776 "Opa" disappeared (with two exceptions) from the literature until it reappeared in the present century in the works of anthropologists. Although Bringas had traveled to the Gila in 1794 he went only as far as the Pima villages on the middle Gila (Ezell 1956:150-58) and both his and Cortez' use of the name are obviously drawn from the sources from which they compiled their reports (Bringas 1819:55 fn; Cortez 1799 MS). For the three quarters of a century following the last Anza expedition there are enough reports available from the Mexican period and the early years of the American period for us to trace the disappearance of the term Cocomaricopa and the emergence of "Maricopa" as the name for the Yuman inhabitants of the Gila and Salt valleys.

Inspection of the documents shows that, where distinctions were made between Opa and Cocomaricopa, they were made on the basis of geographic location - in fact, only on that basis. For the Jesuit period nothing can be discerned if we begin with it; instead the first light is shed in the documents for the Franciscan period. A summary of the applications of the terms in Figure 2 shows 


\begin{tabular}{|c|c|c|c|c|c|c|c|c|c|c|c|}
\hline & $\begin{array}{c}\text { San } \\
\text { Bernardino }\end{array}$ & $\begin{array}{l}\text { Agua } \\
\text { Caliente }\end{array}$ & (unnamed) & Aritoac & $\begin{array}{l}\text { San Diego } \\
\text { (Uitorrum) }\end{array}$ & $\begin{array}{l}\text { San } \\
\text { Martín }\end{array}$ & Uparsoytac & $\begin{array}{l}\text { Ogia- } \\
\text { tagiou }\end{array}$ & Tugsapi & Tucabi & $\begin{array}{l}S \\
0 \\
u \\
r \\
c \\
e \\
s\end{array}$ \\
\hline 1770 & & & & & & & C & ${ }_{\mathrm{P}}^{\mathrm{Opa}}$ & $\stackrel{\text { Opa }}{\mathrm{P}}$ & $\begin{array}{l}0 \mathrm{pa} \\
\mathrm{P}\end{array}$ & 1 \\
\hline \multirow{3}{*}{1774} & $\begin{array}{r}\text { Cocomaricopa } \\
P \text { (one) }\end{array}$ & & & & & & $\begin{array}{l}\text { Cocomaricopa } \\
\text { with Opa } \\
\text { P }\end{array}$ & & & & 2 \\
\hline & Cocomaricopa & & & & & Opa & Opa & & & & 3 \\
\hline & Cocomaricopa & & $\begin{array}{l}\text { Tutumaopa } \\
\mathrm{J}\end{array}$ & Cocomaricopa & Opa & Opa & Opa & & & & 4 \\
\hline \multirow{2}{*}{1775} & & Cocomaricopa & & & & Opa & Opa & & & & 5 \\
\hline & & $\begin{array}{c}\text { Opa or } \\
\text { Cocomaricopa }\end{array}$ & & & Opa & Opa & $\begin{array}{c}\text { Opa or } \\
\text { Cocomaricopa }\end{array}$ & & & & 6 \\
\hline 1776 & & Cocomaricopa & & & Opa & & & & & & 7 \\
\hline
\end{tabular}

Figure 2: Ethnography of the lower Gila, 1770-1776.

$$
\begin{aligned}
& \text { C_ "people from the Colorado" } \\
& \text { J_ "Jalchedunes" (Halchidhoma) } \\
& \text { P_ "Pimas" }
\end{aligned}
$$

that settlements below San Diego - at the east side of the Painted Rocks Mountains - were most frequently identified as Cocomaricopa, whereas those upstream from that range were most frequently identified as Opa. In addition, it is pertinent to note the Spanish practice of listing populations in order of their geographic location relative to each other as well as to the informant and to features of the terrain; in this case, the operative feature was the Gila with its riverain populations. That this was not happenstance is apparent not only in the repeated instances where it was done (e.g., Kino 1948:I:249; Manje 1954:222; Sedel-
1. Garcés (1770 MS)

2. Anza (Bolton 1930:11:122-26)

3. Díaz (Bolton 1930:11:300-304)

4. Garcés (1775 MS; Bolton 1930:11:375-77)

5. Font (Bolton 1930:IV:51-58)

6. Garcés (1900:1:113-24)

7. Garcés (1900:11:436,455)

mayr 1744 MS, 1746 MS), but also in Kino's explicit statement that he was told that "the Yumas, Cutganes, and Alchedomas came next in order" on the Colorado (Kino 1948:I:195). Now it can be seen that his earliest statement regarding populations on the Gila, in which he listed them in order "Opas and Cocomaricopas" (1948:I:128) was not necessarily accident rather, they were named to him in order of their geographic relationship to his informants, the Gila Pimas. That some interpretations of the ethnogeography of the area during the Jesuit period included the conclusion that Opa referred to the 
occupants of the valley in the Gila-Salt junctionGila Bend region is expressed in the appearance of the name in that area on the N. de Fer map of 1700 as cited by Schroeder, who has adequately summarized the published literature on this point (1952:163).

On the occasion of his first reported visit to the Gila Pimas, Garcés wrote that they said the Opas and Cocomaricopas were friends of theirs and pointed out the Opas "between north and west" (Garcés $1770 \mathrm{MS}$ ), a directional designation from that locality indicating the Gila-Salt junction to Gila Bend portion of the river. The next year the Papagos at Cubbos (modern $G u$ $V o$ ?) told him of the "aversion to the Yumas held by the Papagos of the north, the Gileños and the Opas" (Garcés 1771 MS), the direction indicated including this time the Gila part way to the Colorado junction. Beyond such inferences, however, the geographic significance of the terms was made explicit by some of the Spanish explorers. In 1775 Font stated that the Cocomaricopas were "the same as the Opas, but are distinguished in name by the district they inhabit" (Bolton 1930:IV:57). Anza, in summarizing with regard to the Gila route between Sonora and California, wrote: "Ascending the Gila from the junction [with the Colorado], ... we come to the first village of the Cocomaricopas, after which come the Opas and Pimas" (cited in Spier 1953:37).

Concurrently, however, the Spaniards made plain their inability to see anything but a possible regional distinction, that in all other respects the people were the same; this regional distinction, furthermore, was not of the same kind as that obtaining for other groups. No stretches of territory serving as buffer zones intervened between communities of the two groups as was the case between the Yumas and their neighbors up the Gila, for example, and, to complicate the picture, some communities consisted of members of both groups. It is easy to see, therefore, why the Spaniards usually referred to them as one people. Spier (1933:37) fastened on the critical point, however, when he concluded that "the natives recognized a distinction between two peoples" (italics mine). The conclusion, then, is that Opa and Co- comaricopa represented at least areal, if not cultural, distinctions perceptible and real to the Indians and given recognition by their use of different terms when referring to those among them whom they identified as belonging to different groups. Although those Spaniards most interested in the people dutifully set down both names, they were unable to regard as distinct groups those people sharing so many physical and cultural traits. It is not merely fortuitous circumstance that writers exhibiting a different focus of interest should record as inhabitants of the lower Gila two groups which demonstrably could not have been so, but whose names included some of the same phonemes present in the names Opa and Cocomaricopa. Manje (1954:122) reported Cocopas - never otherwise reported as residing elsewhere than in the delta region of the Colorado - as living near Gila Bend; Polici (1697 MS) coupled the Opata with the Cocomaricopa; Croix $(1941: 222)$ in 1781 wrote of the need for missions on the Gila among the Opatas and Pimas, and either the paleographer of the Rudo Ensayo in 1863 or the translator in 1894 was apparently of the opinion that Opa was a mistake for Opata (Rudo Ensayo 1951:3 fn). The linguistic implications of the names thus offer another approach to the problem of their ethnic signification.

Comparison of Indian names recorded by the Spaniards as pertaining to the lower Gila region (and one for the Colorado belcw the Gila-Colorado junction ) - Cocomaricopa, Opasoytac, Tutumaopa, and Guicamcopa, to choose one of the several variations of each - shows that all have in common another term which, in addition to forming part of these combinations, appears by itself. The assumption, then, is that Opa - or Upa, Oopa, Uparch, Uparsh - represents a basic term, a stem, to which were added modifiers in the form of prefixes and/or suffixes in order to convey a special meaning for each new combination thus formed. Before proceeding further with any attempt at linguistic analysis it is perhaps necessary to attempt to determine whether the word is of Piman or Yuman origin. Spier (1933:37 fn.) suggests its possible derivation from the "common Yuma stem apa, 'man,'" whereas Schroeder 
(1952:164) cited Underhill for the derivation of the name from the Piman word aw-pap, "meaning 'stranger' or 'enemy.' "An examination of Yuman linguistics (Halpern 1946, 1947) shows that the phonology and grammatical processes of Yuma are such that a Yuman derivation for words including opa as a component is improbable. For example, the Yuman morphemes connoting "man," "human," "person," "people," all include the morpheme ipa, wherein the vowel immediately preceding the $p$ is always given as $i$, never as $o$ or even $a$ (Halpern 1946:204-10). An assumption that opa was thus a Yuman term requires an explanation of the considerable difference in recording on the part of the Spaniards in setting down $o$ for $i$, when they rendered other sounds with sufficient accuracy that Jalchedun can be confidently identified as Halchidhoma.

Furthermore, Yuman designations for congener groups are composed of a directional morpheme to which is suffixed a morpheme having the connotation of movement, neither of which is found in the terms opa or cocomaricopa. Thus there were the matxalycado' $m$, "those who turned north" (Halpern 1946:25, spelling simplified). Had the designations for the eastern Yumans during the Hispanic period been derived from a Yuman source we might expect to find a Spanish approximation of some such terms instead of the linguistically incongruent Opa/Cocomaricopa. Keeping in mind, however, that from the beginning of Spanish exploration of the area their interpreters were almost invariably Piman, the assumption seems valid that the Spaniards heard the word primarily from the Piman-speaking guides and others, if from the Yuman-speaking peoples at all. Spier's informants identified place names as Piman and Spier commented: "It is also clearly implied that under Piman tutelage he [Kino] designated the Cocomaricopas and Opas separately" (1933:28 fn. 31). In fact, some of the statements indicate that Spaniards were limited to the use of Pima in communicating with the Yuman-speaking peoples so long as their contacts were only those short and intermittent ones resulting from their travel through the area (e.g., Manje 1954:112-13; Kino 1948:I:195). This use of
Pima as the medium of communication among three peoples of mutually unintelligible languages is further illustrated in the circumstance that many of the Yuman-speakers learned both Spanish and Pima and thus served as interpreters as recently as the mid-nineteenth century (Bartlett 1854:II:213).

The linguistics of the rest of the terms support the conclusion that $O p a$, like the others, was a Piman rather than a Yuman appelation. Oitac, for example, is a common component of place names in Pimería (appearing also as oidak, oitag, and oidag) where the association is with plant cultivation, so that it is ordinarily translated as "field," as in Sonoyta (also Sonoydag, Sonoitac, etc.), "Wet Field" (literally, "water-associatedwith-field"). Oitac iself is a combined term, composed of the morphemes oi, to farm, and tac (now more frequently written as $d a k$, but in the past also as $b a c$ as well as the versions given above), a locative translated variously as "be," "is," "sits," etc. Opasoitac, then, identifies the "place where Opas cultivate," to give it the most literal translation, or the more simple "Opa Farms." The $s$ between the morphemes is in this case not the usual Piman emphasis morpheme but a Piman linguistic device for relating an action to the human performer, the "-er" morpheme of English, seen in the Pima word for farmer oisikam (the $i$ being virtually unvoiced). Where the initial morpheme opa stands alone, the $s$ as a suffix can, on contextual grounds, be discounted as the Spanish method of pluralization. The appearance of $r$ following the terminal vowel of the stem, either as it stands alone or as it is combined with the suffix, probably represents Spanish attempts to reproduce the Piman phoneme recorded by Russell (1908:23) as $r s$ which approximates the phoneme in English rendered as "sh," and would account as well for the terminal $c h$ and $s h$ recorded by some of the Jesuit period diarists who, for whatever reason, did not record the oidak part of the name. Another example is seen in the name Sudac-sson (Sedelmayr 1746 MS) for the settlement in the locality for which Russell (1908:23) recorded the name Rso'tuk, Sedelmayr's double $s$ being an attempt to indicate the "sh" sound. The 
$u$ variation of the initial phoneme of the stem may represent Spanish attempts to reproduce a Pima phoneme which is most easily described as the "aw" sound of such a word as "law." This phoneme was characteristically recorded by the Spanish writers as $o$, however, and opa is thus the most common version of the stem. Middendorff's (1957) oopa as part of Cocomaric-Oopas evidently represents an attempt to emphasize the long character of the phoneme (Bloomfield 1948:549) rather than an attempt to approximate a sound for which Spanish has no orthographic symbol.

The Tutuma-opas of Díaz (Bolton 1930:I:301), and Garcés (Bolton 1930:II:387), also recorded by the latter as Chuchuma Opa (Garcés $1776 \mathrm{MS}$ ), were thus distinguished from the other Opas by their residence near the hill called Tumac, on the north side of the Gila downstream from the Painted Rock Mountains (Sedelmayr 1746 MS). The Guicamcopas (also Guicomopas) of Sedelmayr (1744 MS, 1750 MS), were perhaps so identified by the Pimas as the "opas farthest down" if the modifier represents a version of the Piman term kuivo (or kuiva), "down" in the sense of gradient. Garcés (1773 MS) identified these people as the same Quicamo opa or Quiquima he met in evidently the same locality on the Colorado below the Gila junction.

Proceeding on the assumption, then, that Opa is of Piman origin, Underhill's interpretation (Schroeder 1952:164) leaves out of account that there are three Pima words having differences of meaning but similar in that they are all combinations of the same stem modified by different suffixes. For simplicity, the phonemes are written here using English orthography to convey the closest approximation of the sounds. Thus aw stands as one symbol representing the vowel sound of the English word "law," in order that a may represent the sound in "father" and $u$ the sound in "but." The long characteristic of a vowel sound is represented by the colon (:). The stem morpheme of the three Pima words is aw:p which, from at least the time of the missionary Cook (MS, not dated but prepared 1870-1900) has served primarily if not solely to refer to the Apache. The addition of the suffix ap to the stem then re- sults in the word aw:pap (aw:pup among the Papagos) which, among both the Pimas and the Papagos is used only to refer to the modern Maricopas (Cook MS n.d.; Henry F. Dobyns personal communication; Ezell field notes; Russell 1908:41, PI. XLIIIb). When the suffix uta (uka) is added to the stem, the resultant term awputa (awpuka) has the meaning of unspecified or generalized "enemy." Since, during the historic period, and by inference in prehistoric times as well, the Piman and Yuman inhabitants of the Gila have maintained amicable relationships with each other, it would seem inexact to attach the connotation of "enemy" to the word aw:pap, particularly when two other Piman words do carry that association. Nor can the connotation of "stranger" be sustained, since both Pima and Papago have terms for that concept which include none of the elements of the above three words but instead are composed of morphemes having associations with negation, knowledge, and person. Nevertheless the common stem in the three terms makes it obvious that all three had a common origin, regardless of their differing application now. A conjectural explanation of the origins of the terms is therefore offered until a systematic etymological analysis is attempted.

Assuming that the terms aw:p and aw:pap were already in existence at the time of first European contact, and have not developed since, it is suggested that the stem $a w: p$ originally carried the associations of "stranger/enemy" and was the term applied by the Piman-speaking inhabitants of the Gila Valley to all non-Pimas and hence to the Yuman peoples during the initial period of contact between them when the first Yuman immigrants settled in the Gila Valley. As the Pimas subsequently either came into hostile contact with new groups or hostility developed between them and groups already in contact, however, it became necessary for them to distinguish between hostile and friendly non-Piman peoples and the one term could no longer suffice. The appellation for the friendly Yuman peoples was therefore modified by the addition of the suffix ap, whereas the addition of the suffix uta (uka) identified enemy in general, awp becoming fixed as the term for the 
particular enemy, Apache. When the Spaniards of the Jesuit period began their explorations of the lower reaches of the Gila and Colorado rivers they had names for some of the Yuman groups which had been provided by earlier explorers; Manje (1954:115) carried a copy of a report of the Oñate expedition when he and Kino first met the Yumas. These names were linguistically $\mathrm{Yu}$ man, not Piman, having been obtained from Yuman-speaking interpreters, and hence the word Opa (aw:pap) was not an element of those names. The Jesuit-period explorers, starting from bases in Pimería, entered the Gila-lower Colorado region with Piman-speaking interpreters, communication between the Spaniards and their interpreters being in Pima which the Spaniards had learned for greater effectiveness in the reduction of Sonora. Because the Jesuit explorations of the lower GilaColorado region were largely for the purpose of learning whether California was in fact an island or a peninsula, the new Yuman groups met were primarily below the Gila-Colorado junction (Kino 1948:I:312-20, 340-45; Sedelmayr 1750 MS). Since they were given names through Pimanspeaking interpreter/guides, those names included the term opa, hence Quicamo opa, Bagiopa, Coanopa, Hagiopa. These groups living south of the Yumas were ordinarily on unfriendly terms with the Yumas (Manje 1954:114; Garcés 1900:II: $450)$ and on friendly terms with the Gila River people, either directly (Spier 1933:42, 44) or indirectly through the Halchidhoma (Bolton 1930: II:387; Garcés 1900:II:450-53; Spier 1933:1118 ). Thus Yuman groups in the Piman-Gila River Yuman power bloc came to be identified in Jesuit times by Piman names built around the stem $a w$ :pap, except for the then upriver Halchidhoma whose name had entered history earlier. The group name which is most prominent in the literature of the Hispanic period, Cocomaricopa, thus represents this root term plus a pluralized modifier.

In keeping with the historic pattern of eastward drift of the Yuman settlers along the Gila, repeated immigration from the Colorado resulted in the first arrivals coming eventually to occupy the upper portion of the lower Gila Valley in proximity to the Pimas. Here they were at the be- ginning of the historic period and, modern linguistics not having developed, the Piman name for them, Opa, became the common appellation through repeated use by Spaniards and Mexicans. These, then, were the descendants of the first Yuman peoples to migrate from the Colorado to the Gila in prehistoric times. As for the time of that exodus, a possible clue has been provided by Rogers (1945:191-93). The drying up of the Blake Sea - a lake which occupied the Salton Sea Basin - in about the fifteenth century A.D. meant that the heavy population of that region was forced to migrate, since the food resources of the area were no longer adequate. Whether Blake Sea refugees attempting to reoccupy the Colorado Valley dislodged Colorado people or whether they continued their migration eastward into the Gila Valley cannot be conjectured, but is of no moment in the present case. One may, however, consider whether the sources of riverain Yuman internecine conflict may not have lain in the competition during the post-Blake Sea dispersal period for habitat areas deemed desirable by them, since the same pattern of conflict did not develop between them and the upland Yuman peoples.

Since it is assumed that Opa was the Piman stem term for Yuman-speaking occupants of the Gila Valley, and that the members of the group designated in the Spanish records by that term by itself constituted, by virtue of that designation and their position of farthest removal from the Colorado River, the earliest Yuman occupants of the Gila Valley, groups designated by other terms consisting of the stem combined with a modifier and occupying positions downstream from the Opa are thereby assumed to have moved to the Gila subsequent to the Opa immigration. As has been shown, the only population of significant numbers other than the Opa was that identified under the rubric Cocomaricopa, living downstream from the Opa, with some communities described as being composed of members of both groups where the territory occupied by each adjoined that of the other. Given the state of amity described for these populations as well as the associated Piman peoples, inter-fingering of occupancy, so to speak, rather than mutually exclusive occupancy, could 
be expected. Spier (1933: 2-4, 11-18) identifies a number of groups - Halchidhoma, Halyikwamai, Kaveltcadom, and Kohuana-as components of the social entity now designated as Maricopas. In referring to this last-named group, however, informants have expressed bewilderment regarding this term. One person thought that perhaps it was a misrendering of the word Kahuéin (cf $\mathrm{Ca}$ juen, Garcés; Cahween, Bartlett:II:251), which was the name of the group to which she, as well as several other individuals, traditionally belonged. These people, all reputed to be related to each other, are nevertheless now classed as members of the Yuma or Maricopa tribes. One may further conjecture that the migration of the aforementioned groups to the Gila and their merging there, which has resulted in the assimilation during historic times of those groups, may have been part of the total process since its inception, so that the Opa themselves may have represented the fusion of a number of groups.

If the foregoing assumptions are correct, other differences, notably of relative numbers and extent of Pima transculturation should be apparent between the group recorded as the Opa and those identified under the names Cocomaricopa and Tutumaopa. Of the three, the Opa should, by the time of the Hispanic accounts, have become the largest Yuman group recognized on the Gila, and the one showing the most transculturation from the Pimas. In respect of numbers, no one ever reported a separate figure for each population, but the way in which the numbers were reported makes possible an estimate and admits of some conclusions as to relative populations. Garcés vacillated between 2,500 and 3,000 as his estimate of the combined population of the Opas and Cocomaricopas (Garcés 1900:I:123, II:442; Bolton 1930:II:375; Garcés 1775 MS), the Tutumaopas being considered part of the Cocomaricopas. Since the former figure was his concluding one it may be accepted for the people from the farthest upriver Yuman settlement (Tucavi) to Agua Caliente, the last one downstream. Anza, however, reported an estimated population of 1,500 for only the settlements from the Bend (Uparsoytac and environs) to Agua Caliente (Bolton 1930:III:31).
In association with Garcés' figure, this would indicate a population of 1,000 for the area upriver from Uparsoytac. Referring to the distribution of people by settlements along the river as given in Figures 1 and 2, it is obvious that Anza was reporting a figure which included the entire Cocomaricopa group but only part of the Opas. It is of course impossible to arrive at any but the most tentative estimates of the proportionate distribution. If it is assumed, however, that the two purely Opa settlements of San Diego and San Martín, together with the Opas present in Uparsoytac (which was apparently predominantly Opa to have received its name) account for an Opa population equal to that of the upriver settlements not included by Anza, then we have a population figure of about 500 for the Cocomaricopas, with 1,000 for the Opas in the downriver settlements and a total population of 2,000 for the Opas. If, on the other hand, we assume that the downriver Cocomaricopa and Opa populations were approximately equal then there would have been about 750 Cocomaricopas to 1,750 Opas. If we assume, because downstream there were three purely Cocomaricopa settlements to two Opa settlements despite the notation by Garcés (1900:I:113-24) that Agua Caliente was "Opa or Cocomaricopa," it seems most probably that it was Cocomaricopa in view of its downstream location - that Cocomaricopas outnumbered Opas in the same proportion in Uparsoytac, we get a Cocomaricopa figure of 900 and a total for the Opas of 1,600. If we assume a proportional representation for the whole population of five to three in favor of the Opas, based on five "pure" Opa villages versus three "pure" Cocomaricopa settlements over both the upstream and downstream stretches, we have approximately 938 Cocomaricopas to 1,562 Opas. In short, so far as the available data go, the Opas were the larger group.

As for relative transculturation resulting from Piman contacts, the practice of the diarists of lumping the Gila River Yuman peoples for descriptive purposes offers little hope at first glance. Díaz, for example, attributed the wearing of a pubic covering and superior management of arms on the part of the Gila River Yuman men, as 
contrasted with the Yumas of the Colorado River, to the contact between the former and the Gila Pimas (Bolton 1930:II: 301-302). Whether that is correct or not, contact had not yet resulted in the adoption on the part of the Gila River Yuman peoples of such Piman elements as irrigation agriculture or unit dwellings instead of extended-family dwellings. Some inferences regarding the relationship between marriage, residence, and domestic architecture may be drawn from statements in the documents.

The translation of the terms emparentados and tripulados as "related to by marriage" and "mixed with" respectively does not convey exactly the same connotations as do those words in their Spanish context. Although literally correct, it is too easy for the one translation to focus attention on the relationship aspect of a marriage, hence upon the affinal relatives, and divert attention from the fact that an individual of one group was married to, hence cohabiting with, an individual of another group. To translate tripulado as "mixed with" is even less exact. Originally referring to the social situation inherent in our term "ship's complement," in that individual members of a ship's crew must function as a unit if a ship is to be sailed successfully, it came to be extended to include any situation where individuals were best described as components of the group. Thus "forming part of the community" would better convey the meaning of the word tripulado in that context.
That the Spaniards used two such different terms is strong indication that they were distinguishing between two different social situations. For ease of presentation, the statements are tabulated in Figure 3 according to their content. Although Sedelmayr never used the term Opa, just as he never used Jalchedun, his statements are distributed according to their reference to specific locations which make it possible, on available distribution data, to relate his comment to one or the other group. Inspection of the tables in Figures 1 and 2 together reveals some interesting points. For one, it becomes apparent that, when anyone took the trouble to be specific rather than express generalizations such as those of Kino, Manje, and Anza, the pattern of "Pima" residence among the Yuman population of the Gila obtained no farther down the river than Uparsoytac at The Bend. The one "Pima or Papago" at San Bernardino is included solely because Anza noted he was there-he was not described as resident there (Bolton 1930:II:122).

The picture of Sand Papagos/Kwahatks living in Yuman settlements all along the upper portion of the lower Gila must then be modified to include it as a permanent feature of only those Yuman settlements from Uparsoytac upstreamthe portion closest to the Pimas. In this connection it is pertinent to call to mind the "Old Pima woman" resident among Yumas at what was probably the San Pedro of Kino's day who entreated

\begin{tabular}{|c|c|c|c|c|c|}
\hline \multicolumn{3}{|c|}{ PIMAS TRIPULADOS: } & \multicolumn{3}{|c|}{ PIMAS EMPARENTADOS: } \\
\hline $\begin{array}{l}\text { Opa/Cocomaricopa } \\
\text { in general }\end{array}$ & $\begin{array}{l}\text { In Cocomaricopa } \\
\text { settlements }\end{array}$ & $\begin{array}{c}\text { In Opa } \\
\text { settlements }\end{array}$ & $\begin{array}{l}\text { Opa/Cocomaricopa } \\
\text { in general }\end{array}$ & $\begin{array}{l}\text { In Cocomaricopa } \\
\text { settlements }\end{array}$ & $\begin{array}{l}\text { In Opa } \\
\text { settlements }\end{array}$ \\
\hline Kino (1) & $\underset{\text { (3) }}{\text { Agua Caliente }}$ & Stuc Cabitic & Kino (1) & & $\begin{array}{c}\text { Stuc Cabitic } \\
\text { (7) }\end{array}$ \\
\hline Manje (2) & $\begin{array}{c}\text { San Bernardino } \\
\text { (4) }\end{array}$ & $\begin{array}{l}\text { Uparsh } \\
\text { (5) }\end{array}$ & Anza (4) & & $\begin{array}{l}\text { Ogiatagiou } \\
\text { (8) }\end{array}$ \\
\hline Sedelmayr (3) & & $\begin{array}{l}\text { Uparsoytac } \\
\qquad(6)\end{array}$ & & & $\begin{array}{l}\text { Uparsoytac } \\
\text { (9) }\end{array}$ \\
\hline Anza (4) & & & & & $\begin{array}{l}\text { Uparsoytac } \\
\text { (10) }\end{array}$ \\
\hline
\end{tabular}

Figure 3: Associations of terms tripulados and emparentados. Sources: (1) Kino 1948:1:246; (2) Manje 1954:122; (3) Sedelmayr 1749 $\mathrm{MS}_{\text {; }}$ (4) Bolton 1930:Il:123-4; (5) Sedelmayr $1746 \mathrm{MS}$; (6) Bolton 1930:IV:52; (7) Sedelmayr $1744 \mathrm{MS}$; (8) Garcés 1770 MS; (9) Garcés 1775 MS; (10) Garcés 1776 MS. 
Garcés that he "should not go to the Cocomaricopas who, jointly with the Opas and Gileños [Gila Pimas] had fought with her relatives two days before," killing a number. This, together with the other relevant data, would suggest that "Pimas" in the Yuman settlements upstream may have meant either Gila Pima or Kwahatk but not Areneño (Sand Papago) who, owing to their place in the friendship-hostility pattern (Ezell 1955:370), may have been limited to residence among the Yumas during this period.

Another point which emerges from study of Figure 3 is that, where marriage was noted in other than general terms, it was only reported as marriage between Pima and Opa, even when localized at Uparsoytac. In short, to those Spaniards who inquired, intergroup marriages were only apparent as marriages between individuals from the two groups in closest proximity.

Although he refused to recognize any difference between Opa, Cocomaricopa, Halchidhoma, or Yuma, Sedelmayr was nevertheless the only one to note one real difference between Yuman and Piman culture of the time. He described how, where there were Pimas living in Yuman communities, "each family has its separate hut" in contrast to the large extended-family Yuman dwellings (1746 MS). This is taken to mean that the "Pima" families resident in the Yuman settlements were entirely Piman, not instances of mixed marriage, since the preference for patrilocal residence among both the Piman and Yuman peoples on the Gila would expectably have militated against the establishment by a Piman groom of his own residence among the Opas. If this preferential residence pattern obtained then, as now, one would assume that Opa brides went to live near their Pima husbands' parental homes, and Pima brides were taken into the households of their Opa husbands' families. An explanation of the occurrence of separate Pima family establishments in Opa communities then seems difficult unless these represented continuing Piman occupancy in localities which once had been solely Piman but which were becoming increasingly Yuman as a result of Yuman migration from farther down the Gila under pressure of Yuma hostility from the Colorado. This, in turn, suggests that those "Pima" residents in Yuma settlements need not have been other than Gila Pimas, still resident in one-time Piman localities, who had not yet joined the eastward drift of their congeners. The possibility that the "Pimas emparentados" or "tripulados" with Opas represent individuals who had left their own groups to join a Yuman community has against it some cogent objections. Despite the traveling propensities noted for the Yuman peoples, the presence of "Pimas" in Yuman communities is not thereby evidence of similar wide ranging on their part, at least during Spanish times. The Pimas, in fact, apparently did not care for travel except for occasional individuals - witness Garcés' repeated experiences with Pima guides who feared to venture far from the home village $(1770,1771 \mathrm{MSS})$. Further, to describe the Opas as those Yuman peoples in closest proximity to the Gila Pimas or Papagos during Spanish times is not to say that their localities were adjacent or contiguous. On the contrary; it was a two-day journey between the Gila Pima and Opa villages (Sedelmayr 1744 MS; Garcés $1770 \mathrm{MS})$. It is suggested, then, that those instances of marriage between Opas and Pimas resulted from special circumstances such as a Pima being unable to find a mate in the community owing to consanguineal obstacles, and marrying an Opa as a substitute. The frequency with which the Spaniards mentioned Opa-Pima marriage does not necessarily mean that such instances were numerous. For one thing, the Yuman and Piman peoples have maintained separate identities after centuries of amicable interaction including intermarriage. For another, the ethnographic evidence indicates that, under conditions of closer contact and even greater interaction during the American period, intermarriage continued to be the exception (Russell 1908:186; Spier 1933:42, 219-28). The Spaniards mentioned it because it caught their attention and provided them with resident interpreters in most communities along the Gila.

Geographical location and the presence or absence of Piman residents thus were two features which served to distinguish between Opa and Cocomaricopa. The meaning of the first part of the modified name should provide a further basis 
for distinction but unfortunately the evidence available does not admit of a translation conclusive enough for such use. There is little possibility that it is other than a Piman term; it, or some portion of it, occurs repeatedly as a place name in the areas where the aboriginal language was Piman - e.g., Babocomari, Comari, and the Papago form, Komalik. Some versions in the documents pertaining to the Gila offer clues to the etymology. Cocomaric-Oopas (Middendorff 1957: 3), Comaric-Opa (Sedelmayr 1744 MS), and Comaricopa (Sedelmayr 1749 MS) are grounds for the conclusion that the root morpheme is komarik. Since pluralization is achieved in Pima by duplicating (usually) the first syllable (e.g., otam, person, o'otam, people), kokomarik would be the plural of komarik. Of the published sources, Lumholtz (1912:381) translates Komalik as "Mountain Crest" and Kukomalik as "Big Mountain Crest," which latter Schroeder (1952:164) combines with aw-pap to identify the Cocomaricopas as "people of the big mountain crest-perhaps the Estrella Mountains.' "Underhill (Schroeder 1952:164) and Jones (n.d.:1), on the other hand, translate it as "flat place" and "Big Flats" respectively. Contemporary Pimas give still another meaning, that of having the sense of convexity ("it has form," accompanied by a gesture of the hands indicating humps or domes) and possibly extended to mean hills. Finally, there appears to be some association with water. Cook (n.d.) gives komarlk as a verb meaning to ford; the place name Comari refers to a watering place (or places) south of the Gila River (Bolton 1930: III:13; IV:32; Ezell 1958:25-26). Similar physiographic features were reported along the Gila in early times as ponds (lagunas) or salt or cane (carrizo) flats in the area occupied by the Cocomaricopas (Bolton 1930:IV:61; Emory 1848:607). It may be that komari refers to a setting characterized by a flat holding a pond and with hills close by. Whatever the meaning, it seems most probable that the descriptive modifier komari was first used to distinguish the downriver from the upriver $a w$ : pap, being retained after memory of its origin had been forgotten and even after the population was no longer associated with that part of the valley and the feature (or features) designated by the term.

The question of the preservation of the name Cocomaricopa for a time at the expense of the term Opa, and of the disappearance of the former in favor of the modern word Maricopa is in large part a function of terrain and lines of communication. Inspection of the historical record shows that travel between Sonora and California involved only part of the lower Gila Valley - that part principally inhabited during Spanish times by the Cocomaricopa. The very first of the Gila River Yumans met in their occupation area were the Cocomaricopa, as Kino and Manje made their first journey along that part of the Gila eastward and up the Gila from the Colorado. Such was also the case with Anza, who led his first expedition to California across Papaguería, bypassing most of the lower Gila, and thus also first met its inhabitants as he proceeded eastward on his return journey. Even in those Opa communities visited there were often Cocomaricopas reported. During the entire period from 1699 to 1852 only three journeys along the Gila between the GilaSalt junction and Gila Bend have been reported, in contrast to the dozens of reports of travels along the downstream portion of the lower Gila. A large portion of the Opa territory and population was thus isolated, as it were, from the main stream of history and contact, whereas the Cocomaricopas were always in a position to be noticed. Priority of contact, together with intensity of contact, thus tended to fix Spanish attention on Cocomaricopas as the primary group, and the apparent cultural identity between them and the Opas who, in the cultural and geographical context of the times, presented the impression of being merely a group peripheral to the Cocomaricopas, reinforced this interpretation of the ethnogeography of the lower Gila.

The foregoing circumstances may have set in action a particular kind of transculturation which further operated to obscure both the name and concept of Opa and to perpetuate those of Cocomaricopa. Even though communication between the Europeans and the Cocomaricopas was by means of Pima in the beginning, the exposure 
to contact with the Spaniards resulted in increased interaction between Cocomaricopas and Spaniards apart from contacts along the river. An additional operative factor may have been an increased receptivity to mobility and change as a consequence of the relatively more recent move of the Cocomaricopas to the Gila. At any rate. by the Mexican period we find that Cocomaricopas were traveling more frequently and widely than were the Pimas, but only one record has been found of an Opa having been met away from Opa territory. Cocomaricopas carried mail, for example, between Tucson and San Diego during the Mexican period (Beattie 1933:57). The first individual of the Gila River populations to make contact with the Kearny party was a Cocomaricopa (Emory 1848:107). The first representatives of the Gila River people whom Bartlett met were Cocomaricopas who had traveled to Ures, Sonora, as a deputation of the governor months before Bartlett reached the Gila (1854: I:451-52). Even he repeated the history of contact, in that he too came east up the Gila and met first the people whom he was prepared to meet first, the Cocomaricopas. By that time the Opas had disappeared from the records simply by default.

Another factor was the aforementioned pattern of assimilation. Together with the common culture configuration of the riverain Yuman groups, these two attributes would have obscured for the Spaniards the strong sense of group identity rather than population identity which so characterized the Yuman population (viz. e.g. Kroeber 1902:278-79). In addition, it is more than probable that the Yuman peoples did not regard, until very late in historic times if then, the Piman names as their proper appellatives. The operation of these factors is apparent in the circumstance that individuals still identify themselves as Kaveltcadom or Halchidhoma while at the same time regarding themselves as members of the larger group now known as Maricopa, a consequence of the administrative structure in effect since 1859 . The situation is to some extent analogous to that of the greater modern population in which individuals identify themselves and are identified by other components of the population as "Mexican-American," "Spanish-Californian," "Spanish-American," etc., although the Yuman individuals so behaving may lack any physical or cultural distinctions (except perhaps a language) from the larger Yuman group.

The evolution of "Maricopa" as an Anglicization of Cocomaricopa can be traced from its beginning in the records of the Kearny expedition. What little in the way of documentary sources was produced by the earliest Englishspeaking visitors to the Gila and Salt valleys the beaver trappers of $1825-30$ - indicates that the modern name had not yet come into existence. Pattie claimed to have met "Cocomarecopper" Indians four days' journey up the Colorado from the mouth of the Gila $(1905: 132)$. Yount's generally consistent use of modern forms of Indian names (Clark 1855 MS) shows that he had refreshed his memory from published sources. Shortening of Cocomaricopa to some version of Maricopa was an innovation (in published works at least) of the Kearny expedition (Emory 1948: 107-108, 168, 561, 599-603; Tyler 1881:236-37) where the change of usage can be followed. The early publication of the reports of the expedition and their popularity among the immigrants to California during the next few years gave greater currency to the shortened name, although the older long form appeared occasionally, as in the works of writers exhibiting literary pretensions (Clarke 1852:91; Bartlett 1854:I:451-53, II:21053 passim). With the establishment of the first reservation for the Indians in the area, the modern form became firmly established as the designation for the amalgamated Yuman-speaking population of the Gila-Salt area (U. S. National Archives, Record Group 75). Cocomaricopa followed Opa into oblivion for over three quarters of a century, its place being taken by an Anglicized word which, because it designates all, cannot with accuracy be used to identify any one component of that population.

Although the information available for the Mexican period is scanty and sometimes ambiguous it appears that some of the Gila River Yuman peoples continued to occupy their posi- 
tions downstream as far as Agua Caliente for at least the interval between the contact last recorded for the Franciscan period and the earliest contacts recorded during the Mexican period. Romero identified as Cocomaricopa the villages he visited in 1823 along the Gila. In the course of this journey he crossed the river in order to reaffirm the alliance with the Cocomaricopas by a meeting with the principal, José Cocomaricopa, (also known as José Gavilán) and the Cocomaricopas living north of the Gila (Beattie 1933: 57; Figueróa $1825 \mathrm{MS}$ ). He returned to the Gila at Agua Caliente, crossed it at the ford of San Pascual at the Mohawk Mountains and, leaving the Cocomaricopas, struck southwest to the Colorado, going through Tinajas Altas Pass in the Gila Mountains (Beattie 1933:57). When Romero was delayed on his return trip in 1825 , Figueróa arranged for an escort to await him at the Cocomaricopa village at Agua Caliente (Beattie 1933:66), also known as El Paronal (Figueróa $1825 \mathrm{MS}$; Ezell 1957:180, where Rivera is erroneously given for Romero).

The available documents for the next twentyone years are of no help. The trappers' accounts (Pattie 1905:121-30; Clark 1855 MS) are so vague and confused that the only item which can be identified as pertaining to the lower Gila is Yount's statement (Clark 1855 MS): "Between the Yumas and Maricopas were found a small thieving tribe, which gave our trappers some annoyance. They stole several animals, and did the party some injury of minor consequence." These could have been either Cocomaricopas or a band of Sand Papagos. If failure to mention a settlement means that there was no settlement there, the latter would seem most probable, but since no better localization can be made, this contributes little to the picture. Mexican reports for the period (Zúñiga 1948; Escudero 1834; Anonymous 1849 MS) either ignore the Yuman-speaking Gila population or fail to localize it. The earliest American period reports indicate that a shift in occupation area had occurred between 1828 and 1846 . The Kearny expedition met no Indians along the lower Gila in 1846, although the existence of house remains indicates occu- pancy of the region of the Bend within a very short time previously (Emory 1848:117-18, 603 ). Two years later Graham's column pastured its stock on corn stubble nine miles below the Tezotal (Couts 1848 MS).

The Kearny reports are also the first to note a Yuman-speaking group settled on the middle Gila (Emory 1848:110-116; Johnston 1848:601602), although the Indian annals (Hall 1907: 415; Russell 1908:38) show that Yuman settlements existed on the middle Gila and middle Salt as early as 1833. Evidently the Yuman population had shifted eastward to the extent that the region of the Bend constituted the downstream perimeter of settlement by 1846-48 at the latest. By 1849 , even that area had evidently been abandoned by them, for none of the many accounts of the gold-seekers mentions any but patrolling "Maricopas" west of Maricopa Wells. For a time during the succeeding quarter of a century there is no evidence of permanent settlements along the lower Gila except for those of the English-speaking immigrants into the area (Browne 1950:8185, 99-104), but Henry F. Dobyns and Robert Thomas (personal communications) obtained statements that the northern band of Sand Papagos (Iatak Kowatam - Gifford 1940:3) and the northern portion of the Hu'ula dialect group of Papagos used it seasonally as part of their range. By the end of that time, however, communities had evidently been established in the Gila BendPainted Rocks area (Childs and Dobyns 1954: 31 ), and in 1882 a reservation was recognized for this Piman-speaking group on the lower Gila.

In 1930-31, Spier (1933:x, xii, 17-18 fn. 31 ) found remnants of five Yuman-speaking groups living on the middle Gila and known collectively as "Maricopa," while at the same time individuals were also self-identified or identified by others as Halchidhoma, Halyikwamai, Kaveltcadom, Kahuéin, or simply Maricopa. Three of these groups - the Halchidhoma, Halyikwamai, and Kahuéin - had not left the Colorado by 1825 and, furthermore, it is clear that they had never lived along the lower Gila. The Halchidhoma were never reported there except as visitors even when they finally abandoned the 


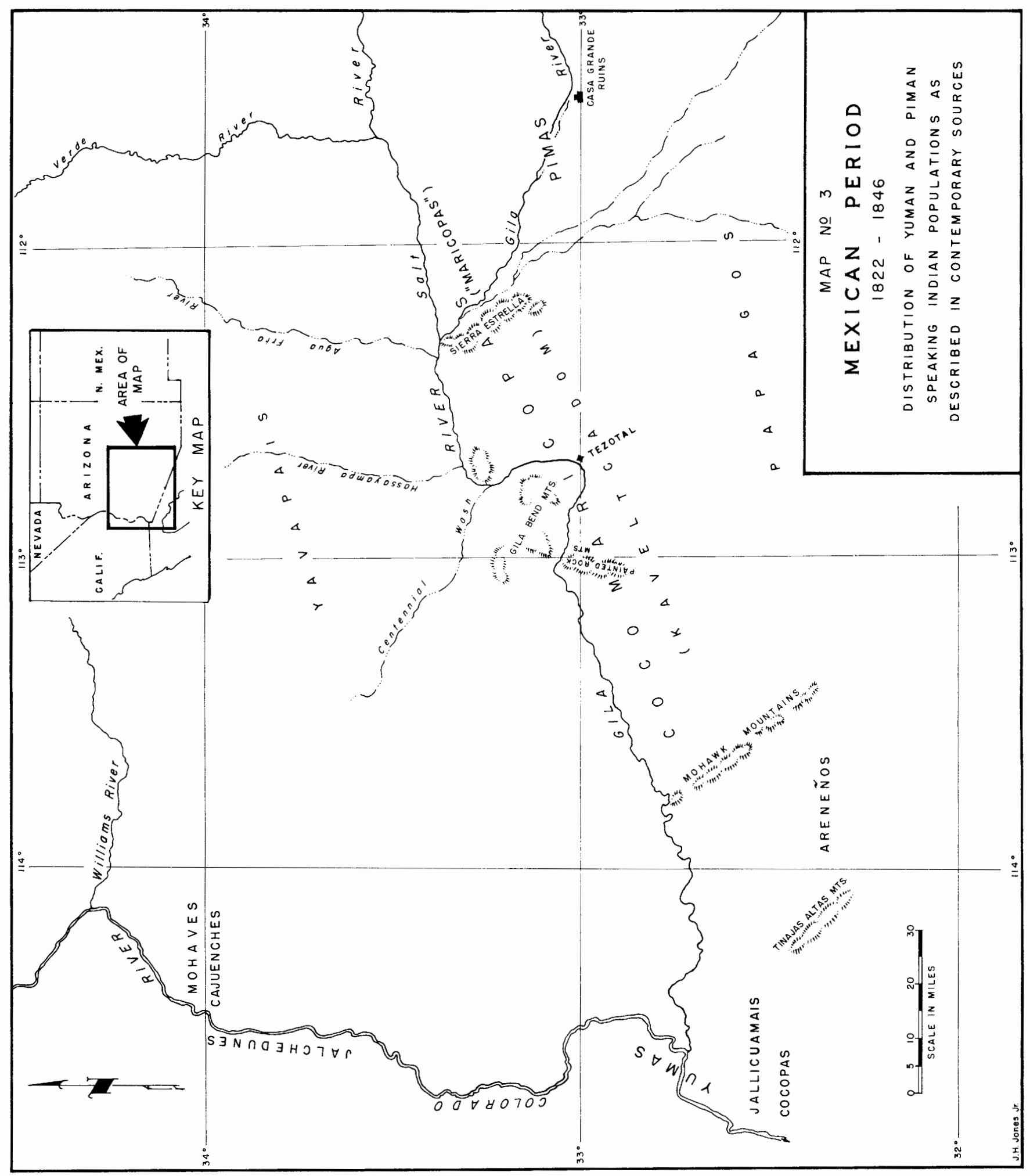


Colorado in 1828 (Spier 1933:14). The Halyikwamai and Kahuéin, by that time forming one group, went directly to the "Maricopa" on the middle Gila in 1838-39 (Spier 1933:17). Of five groups, then, only two, identified as Kaveltcadom and "Maricopa," could have been associated with the lower Gila. For our problem - the ethnohistoric identification of the group or groups once occupying the Painted Rocks Reservoir area the principal basis for distinction between the two is the traditional and historic evidence of different geographical association for each.

The Kaveltcadom, according to Spier's Halchidhoma and "Maricopa" informants, were a branch of the Halchidhoma which had left the Colorado so long before the final hegira that "tradition no longer preserves any precise mention of it" (Spier 1933:12). As no name identifiable as Kaveltcadom is reported for the Colorado population, it is assumed that their departure was before the historic period. According to their own traditions the Kaveltcadom, prior to their arrival on the middle Gila, had only lived along the lower Gila from the Mohawk Mountains upstream to Gila Bend and possibly as far as Centennial Wash, until at least 1835 (Spier $1933: 9,11-12,15-16,24-25,29)$. By 1846 at least, and not later than 1849 in any case, the Kaveltcadom no longer had settlements along the Gila at the Bend or downstream. Spier (1933: 40) has shown that by 1852 they were settled on the middle Gila, with the one settlement as far downstream as Centennial Wash possibly still occupied.

The remaining group, for which Spier's informants could give no other identification than "Maricopa," were supposed not to have had any tradition of ever having lived elsewhere than along the middle Gila (Spier 1933:1, 26). The Halchidhoma-Kaveltcadom body of tradition suggests that this means of preserving such details as geographic locations and movements specific enough for ethnohistoric reconstructions was valid for approximately a century preceding the time Spier worked. This would explain why some "Maricopas" had no tradition of having lived elsewhere than along the middle Gila, whereas other accounts place "Maricopas" on the lower Salt in the early part of the nineteenth century. In addition to the traditional records noted by Hall and Russell which have been cited, the Kaveltcadom-Kahuéin annalist cited by Spier (1933:40) recorded the removal of "Maricopas" from a settlement on Salt River opposite Phoenix to the community near the Gila-Salt confluence in 1869-70. This man in turn had learned of the events he recorded for the period prior to 1873-74 - the year he began keeping the rod - from an older man of another "Maricopa" community on the Salt near Mesa (Spier 1933: 138). In addition, some details in other accounts suggest corroboration of the early existence of Yuman settlements on the Salt and a partial explanation of this lacuna in tradition.

In the version of the Pima creation myth recorded by Russell (1908:215), the "Maricopas" were described as united with the Yumas at first then leaving the Yumas and joining the Pimas, "finally settling in the Salt River valley, where they formed permanent settlements." Experiencing difficulty in building canals, they were described as applying to Pima supernaturals for aid. Comparison of this account with the one recorded 127 years earlier by Font (Bolton 1930: IV:40; Russell 1908:212 fn) shows that at that time a Yuman-speaking group had been located downstream from the Pimas long enough for their arrival to have been rationalized into mythological form. Incidentally, in the Font version, that group was identified as Opa - the Cocomaricopa were not included in Pima mythology of 1775 .

The only traditional account given by Russell of Yuman peoples coming to the Gila-Salt region, as contrasted with a mythological account of their origin there, is this statement: "For a long time prior to 1833 the Maricopas lived at Gila Bend. ... Soon after that time they settled beside the Pimas" (1908:93). On the internal evidence this would be taken to mean that Russell was extending the Kaveltcadom story to stand for the entire Yuman population of the Gila and Salt. A tradition, including the elements of a "Maricopa" delegation to the Pimas in advance of settlement and the agreement upon which the settlement was 
supposed to have been based, was given, however, by elderly Pimas as late as 1955 (Ezell, field notes). The account of approximately the same era as Russell given by Parish (1915:II: 26-29), while inaccurate in the light of present knowledge, contains circumstantial details in addition to those given by Pimas in 1955 suggesting that it had been obtained from informants of the Gila River Yuman aggregate group rather than from the Pimas, although it parallels the Pima account. Both versions, however, include the element of exodus from the Colorado. These accounts would refer to the Halchidhoma-Halyikwamai-Kahuéin movements but, as a function of the time limit on tradition observed for the $\mathrm{Ka}$ veltcadom, are extended to describe all "Maricopa" and to combine into one the moves from the Colorado and the lower Gila to the middle Gila and lower Salt.

To recapitulate, a number of terms occurring in the literature as referents for the Indian population are separable into two groups according to their occurrence and usage. One set can be called the "historical" terms, since they are characteristic of that class of records. In this list two names - Opa and Cocomaricopa - are significant for this study as identifying two components of the Yuman population of the area concerned. The other set can be called the "ethnographic" terms, as their associations are with that context rather than with historical records. Of this list one name - Kaveltcadom - has significance for this study as identifying a component of the Yuman population of the area. Two names - "Pima" and "Maricopa" - identify Piman and Yuman components respectively of the Indian population of the Gila and Salt valleys, and appear as both historical and ethnographic terms. Owing to variations of usage these two terms are susceptible of equivocation or ambiguity.

In the historic records, the name Cocomaricopa has a dual application. It is used as a generic term for the entire Yuman population of the Gila and Salt rivers (and, by one writer, to include one component of the Yuman population of the Colorado River as well). It is also used to designate that portion living along the Gila
River from the Painted Rocks Mountains downstream. The name Opa, on the other hand, is only used in reference to those Yuman settlements along the Gila from the Painted Rocks Mountains upstream to the vicinity of the Hassayampa. As a function of the history of Indian-White contact, the generic term Cocomaricopa supplanted the specific term Opa in the historic records, and agents of a new immigrant culture pattern shortened that name to Maricopa, still as a generic term and only so. The name "Pima," when used in connection with that portion of the Gila along which Yuman peoples lived, is never used to identify communities, but only to refer to individuals as components of Yuman communities. In that context it represents a generic term distinguishing between members of two linguistic groups, rather than between populations of one linguistic group.

The ethnographic term Kaveltcadom refers to that portion of the Yuman population of the Gila-Salt region identified by the Indians as having lived along the lower Gila until about the middle of the nineteenth century. At this point in time they moved eastward, becoming part of the Yuman population already established upstream and ceasing to exist as a separately identifiable group, although individuals continued to be identified as Kaveltcadom as well as members of the aggregate Yuman population identified ethnographically and historically under the name "Maricopa." Whereas "Maricopa" never had a specific, but only a generic application in the historic records, ethnographically it has dual application. In addition to its generic usage it has also been used to refer to the larger portion of the Gila River Yuman population which has no tradition of residence on either the Colorado or the lower Gila. The remaining term, Pima, is used ethnographically to identify a population living along the Gila rather than to identify individuals linguistically distinguishable in a Yuman community.

Thus we have two Yuman groups identified in the historic records, and two groups identified ethnographically, with four names which do not admit of continuity of identification from one set 
of records to the other on the basis of names alone. Two of the terms occur only in the historical sources, one occurs in the ethnographic record alone, and one is used in both. The two historical names, Opa and Cocomaricopa, identify Yuman groups separable on the bases of geography and numbers. The Opa were farthest upstream and closest to the Gila Pimas, most numerous, but so located that there was less contact between them and the Whites than was the case of the Cocomaricopas. The latter were in the downstream position, fewer in number, but exposed to the most White contact and most exposed to the pressure of the hostile Yumas of the Colorado. As a function of Indian-White contact, however, the name of the smaller group came to be used by writers as a generic term for the entire Yuman population of the Gila, and its perpetuation at the expense of the name of the larger (but in those circumstances more isolated) group is discernible as an historic process. The modification into the name Maricopa of the form of the term thus developed, with no change from its purely generic significance, can likewise be traced as an historic process.

The ethnographic term Kaveltcadom identifies those of the Yuman population who were the last occupants of the downstream position with reference to the larger portion of the Yuman population identified ethnographically as Maricopa. Thus used, however, "Maricopa" has dual significance in contrast to its single meaning in the historic context. It serves as the specific designation for this upstream Yuman population, apart from the Kaveltcadom, which had no tradition of residence on either the Colorado or the lower Gila, hence a population which had been established in its locale for a longer period of time than that covered by Kaveltcadom tradition. It also serves, as it did in the historical context since the mid-nineteenth century, as a generic term referring to the aggregate population of the Gila-Salt area.

The evolution of Cocomaricopa into Maricopa is clear insofar as the terms themselves go, but that this also signifies that the continuity between the peoples identified by the terms follows upon that development is open to some difficult questions.

If the Cocomaricopa from the Gila below Painted Rocks became the Maricopa of the GilaSalt above the confluence, they must have moved to their upstream position before the Painted Rocks-Centennial Wash stretch was abandoned in order for them to have been there for the Kaveltcadom to have joined them by the midnineteenth century at the latest. Since both Kaveltcadom and Halchidhoma traditions extended back approximately a century to the third decade of the nineteenth century, it would be surprising if Maricopa tradition would not have extended equally far. Such a move on the part of the Cocomaricopa would then have presumably occurred prior to the 1830's. But the historical sources establish the Cocomaricopas on the lower Gila as far down as below the Painted Rocks Mountains until that time at least, and possibly for the next decade as well. Furthermore, such an early move on the part of those Cocomaricopas would have apparently left the inhabitants of the Painted Rocks-Centennial Wash stretch of the Gila in position to become designated as the Cocomaricopas of the 1830's, thus providing two candidates for the position of "ancestors of the Maricopas." The same objection of discrepancy of traditional preservation of knowledge of such former location would obtain, as well as that of necessitating a third group, for which there is no other evidence.

In addition, ethnographic evidence shows that the Kaveltcadom occupied the Painted RocksCentennial Wash portion until the 1830's at least, after which they withdrew upstream to join an already established Yuman population, the existence of which is established by historical sources for as early as the time when the Kaveltcadom were still on the lower Gila. Since the ethnographically defined Kaveltcadom area comprised that of both the historically identified Opa and Cocomaricopa, it might be argued that both groups became amalgamated to form the one later identified as Kaveltcadom. Such an interpretation leaves the upstream group unaccounted for, and is inconsonant with the population figures for the 
various groups. If it is argued that only the Opa were the Kaveltcadom and that the Cocomaricopa abandoned their downstream position with reference to the Opa, moving past them to become the Maricopa upstream, then a marked reversal of relative populations would have to be assumed also, as well as an expansion of Opa Kaveltcadom settlement pattern downstream for Kaveltcadom tradition to have preserved those downstream locations. Both of these changes of locale would have been at variance with the pattern of population movements on the Gila, which was one of drift by a few individuals, rather than migrations of whole communities.

My own conclusions can be stated as a series of propositions as follows:

1. That the Opas, on the grounds of the name being a basic element of many Piman terms, their location farthest upstream and in closest proximity to the Pimas, their greater numbers, and their presence in Pima mythology, were the earliest Yuman population to settle on the Gila;
2. That the Cocomaricopas, on the grounds of their name being a modification of Opa, their downstream position farthest from the Pimas, their fewer numbers, and their absence from Pima mythology, were later arrivals on the Gila than the Opas;

3. That the group identified only as "Maricopas," on the grounds of their greater numbers, and their lack of any tradition of having lived on the lower Gila, were the first Yuman settlers on the middle Gila;

4. That the Kaveltcadom, on the grounds of their fewer numbers, their tradition of having lived on the lower Gila and having moved to the middle Gila, were later arrivals on the middle Gila;

5. That "Maricopa," when used in other than a generic sense, is therefore equivalent to Opa; and

6. That the Kaveltcadom represent the Cocomaricopa. 


\section{BIBLIOGRAPHY}

\section{ANONYMOUS}

1849 [to] Presidente de la Junta de Colonización é Industria. Ures [Sonora], September 13. MS in Archivo Histórico del Estado, Museo y Biblioteca del Estado, Hermosillo.

ANZA, JUAN BAUTISTA DE - See Bolton

\section{ARGUELLO, JOSE}

1797 Informe ... del numero de naciones de yndios gentiles que sitan las marjenes del Río Colorado desde el desemboque al mar del Golfo Californica. . . . Monterrey [California], February 28. MS in Bancroft Library, Berkeley.

\section{ARRICIVITA, JUAN DOMINGO}

1792 Crónica seráfica y apostólico del Colegio de Propaganda Fide de la Santa Cruz de Querétaro en la Nueva España. Segunda Parte. México: Don Felipe de Zúñiga y Ontiveros.

BANCROFT, HUBERT HOWE

History of the North Mexican States and Texas.

1884 Vol. 1, 1531-1800. San Francisco: A. L. Bancroft and Co.

1889 Vol. 2, 1801-1889. San Francisco: The History Co.

BARTLETT, JOHN RUSSELL

1854 Personal Narrative of Explorations and Incidents in Texas, New Mexico, California, Sonora, and Chihuahua. New York: D. Appleton and Co. $2 \mathrm{v}$.

BEATTIE, GEORGE W.

1933 Reopening the Anza Road. Pacific Historical Review, 2:52-71.

\section{BLOOMFIELD, LEONARD}

1948 Language. 2d ed. New York: Henry Holt and Co.

BOLTON, HERBERT EUGENE (tr.)

1930 Anza's California Expeditions. Berkeley: University of California Press. 5 v.

BRINGAS DE MANZANEDA, DIEGO

1819 Sermon que en las solemnes houras celebradasen obséquio de los VV. PP. . . Madrid: D. Germin Villalpondo, Impresor de Camara de S. M.

BROWNE, J. ROSS

1950 A Tour Through Arizona 1864, or Adventures in the Apache Country. Tucson: Arizona Silhouettes. Reprint.
CARSON, KIT

1926 Kit Carson's Own Story of His Life as Dictated to Col. and Mrs. D. C. Peters About 1856-57. ... Edited by Blanche C. Grant. Taos, N. M.

CHILDS, THOMAS, AND HENRY F. DOBYNS

1954 Sketch of the "Sand Indians." The Kiva, 19: 2-4, 27-39.

CLARK, ORANGE

1855 Biography of George Calvert Yount. MS in Bancroft Library, Berkeley.

CLARKE, A. B.

1852 Travels in Mexico and California. Boston: Wright and Hasty's Steam Press.

CLELAND, ROBERT GLASS

1950 This Reckless Breed of Men: The Trappers and Fur Traders of the Southwest. New York: Alfred A. Knopf.

COOK, CHARLES H.

n.d. Pima. Transcribed from the original by Mrs. John W. Murphey. MS in Arizona Pioneers' Historical Society, Tucson.

CORTEZ, JOSÉ

1779 Memoria sobre las provincias del norte de Nueva España. MS in Special Collections Division, University of Arizona Library, Tucson.

COUTS, CAVE JOHNSON

1848 Diary of a March to California, 1848. MS in Bancroft Library, Berkeley.

CROIX. TEODORO DE

1941 Teodoro de Croix and the Northern Frontier of New Spain, 1776-1783. Translated and edited by Alfred B. Thomas. Norman: University of Oklahoma Press.

\section{DECORME, GERARD}

1941 La obra de los Jesuitas Mexicanos durante la época colonial, 1572-1767. México: Antigua Librería Robredo de José Porrúa é Hijos. 2 v.

\section{DENHARDT, ROBERT MOORMAN}

1941 Driving Livestock East from California Prior to 1850. California Historical Society Quarterly, 20:341-47.

DÍAZ, JUAN - See Bolton 
EMORY, WILLIAM H.

1848 Notes of a Military Reconnoissance, from Fort Leavenworth, in Missouri, to San Diego, in California. House Exec. Doc. 41, 30th Cong., 1st Sess. Washington: Wendel and Van Benthuysen, Printers.

ESCOBAR, FRANCISCO DE - See Hammond and Rey

ESCUDERO, JOSÉ AUGUSTÍN DE

1834 Noticias estadísticas de Sonora y Sinaloa. México: Tipografía de $R$. Rafael.

EZELL, PAUL $\mathrm{H}$.

1955 The Archaeological Delineation of a Cultural Boundary in Papagueria. American Antiquity, 20:4:367-74.

1956 Fray Diego Bringas, a Forgotten Cartographer of Sonora. Imago Mundi, 13:151-58.

1957 The Conditions of Hispanic-Piman Contacts on the Gila River. América Indigena, 17:163-91.

1958 An Early Geographer of the Southwest: Father Diego Bringas. El Museo, 2:2:18-29.

FAGES, PEDRO

1913 The Colorado River Campaign 1781-1782. Translated and edited by Herbert I. Priestley. Berkeley: University of California Press. Publications of the Academy of Pacific Coast History, Vol. 3, No. 2.

FARISH, THOMAS E.

1915 History of Arizona. Vol. 2. San Francisco: The Filmer Brothers Electrotype Co. 8 v.

FIGUERÓA, JOSÉ

1825 [Letter] to Secretaría del Estado y del Despacho de la Guerra y Marina, México. Arizpe [Sonora], September 6. MS in Archivo Histórico Militar, México.

FONT, PEDRO - See Bolton

\section{GARCÉS, FRANCISCO}

1770 Diario que se ha formado por el viaje hecho al Río Gila. ... . San Xavier del Bac. Historia, Tomo 396. MS in Archivo General de la Nación, México.

1771 Diario que se ha formado con la ocación de la entrada que hise a los besinos gentiles. San Xavier del Bac. Historia, Tomo 396. MS in Archivo General de la Nación, México.

1773 [Letter] to Antonio María Bucareli y Ursua. Cieneguilla [Sonora], November 21. Provincias Internas, Tomo 82. MS in Archivo General de la Nación, México.

1775 Copias de las notícias sacádas. . . . Santa Cruz de Querétaro. Bolton transcripts: Copia de barios papeles del R. P. Fr. Franco Garces, Bundle $\mathrm{H}$, Item No. 6. MS in Eugene C. Baker Texas History Center, Austin.
1776 [Letter] to Fr. Diego Jimenez, M.R.P. Guardian. Bolton transcripts: Copia de barios papeles del R. P. Fr. Fran.co Garces, Bundle H, Item No. 5. MS in Eugene C. Baker Texas History Center, Austin.

1900 On the Trail of a Spanish Pioneer: The Diary and Itinerary of Francisco Garcés (Missionary Priest) in his Travels Through Sonora, Arizona and California, 1775-1776. Transiated and edited by Elliot Coues. New York: Francis P. Harper. $2 \mathrm{v}$.

GIFFORD. E. W.

1940 Culture Element Distributions: XII - Apache. Plleblo. Anthropological Records, Vol. 4, No. 1. Berkeley: University of California Press.

GOULDING, WILLIAM R.

1849 Diary, 1849. MS in Yale University Library, New Haven.

HALL. SHARLOTT

1907 The Story of a Pima Record Rod. Out West, 26:413-23.

HALPERN, A. M.

1946 Yuma I, II, III. International Journal of Linguistics, 12:1:25-33;12:3:147-51; 12:4:205-12.

1947 Yuma IV, V, VI. International Journal of Linguistics, 13:1:18-30;13:2:92-107; 13:3:147-66.

HAMMOND, GEORGE P. AND AGAPITO REY

1953 Don Juan Oñate, Colonizer of New Mexico, 1595-1628. Albuquerque: University of New Mexico Press. 2 v. Coronado Cuarto Centennial Publications, Vols. 5 and 6.

JOHNSTON, A. R.

1848 Journal of. . . In Emory (see above), pp. 567-614.

JONES, ALDEN

n.d. Place Names on the Papago, Gila Bend and San Xavier Indian Reservations. Sells: Sells Indian Agency, Office of Indian Affairs.

KINO, EUSEBIO FRANCISCO

1948 Kino's Historical Memoir of Pimería Alta. Translated and edited by Herbert E. Bolton. $2 \mathrm{~d}$ ed. Berkeley: University of California Press. $2 \mathrm{v}$.

KROEBER, A. L.

1902 Preliminary Sketch of the Mohave Indians. American Anthropologist, 4:2:276-85.

LUMHOLTZ, CARL

1912 New Trails in Mexico. New York: Charles Scribner's Sons. 
MANJE, JUAN MATEO

1954 Luz de tierra incógnita: Unknown Arizona and Sonora, 1693-1721. Translated and edited by Harry J. Karns and associates. Tucson: Arizona Silhouettes.

MIDDENDORFF, BERNARD

1957 Letter of Father Middendorff, S. J. The Kiva, 22:4:1-10. Translated by Arthur D. Gardner.

NENTUIG, JUAN - See Rudo Ensayo

\section{PALOU, FRANCISCO}

1926 Historical Memoirs of New California. Translated and edited by Herbert E. Bolton. Berkeley: University of California Press. 4 v.

PATTIE, JAMES OHIO

1905 Pattie's Personal Narrative of a Voyage to the Pacific and in Mexico, June 20, 1824-August 30, 1830. Cleveland: The Arthur H. Clark Co. In Early Western Travels 1748-1846, Vol. 18, editied by Rueben Gold Thwaites.

POLICI, P. V. HORACIO

1697 Relación del estado de Pimería que remite el ... por el año de 1697. Dolores [Sonora], December 23. Historia, Tomo 16. MS in Archivo General de la Nación, México.

\section{RICHMAN, IRVING BERDINE}

1911 California Under Spain and Mexico, 1535-1847. New York: Houghton Mifflin Co.

ROGERS, MALCOLM J.

1945 An Outline of Yuma Prehistory. Southwestern Journal of Anthropology, 1:2:167-98.

\section{RUDO ENSAYO}

1951 Rudo Ensayo by an Unknow'n Jesuit Padre, 1763. Tucson: Arizona Silhouettes, Reprint.

\section{RUSSELL, FRANK}

1908 The Pima Indians. Annual Report, Bureau of American Ethnology, No. 26, pp. 3-390.

SCHROEDER, ALBERT H.

1952 Documentary Evidence Pertaining to the Early Historic Period of Southern Arizona. New Mexico Historical Review, 27:2:137-67.

1961 An Archaeological Survey of the Painted Rocks Reservoir, Western Arizona. The Kiva, $27: 1: 1-28$

\section{SEDELMAYR, JACOBO}

1744 [Letter] to Juan Antonio Balthasar, Visitador General. Tubutama [Sonora], October 7. Archivo Franciscano, Provincias Internas, Californias, Carpeta 37/65. MS in Biblioteca Nacional, México.

1746 Relación que hizo. . . . México, February. MS in Arizona Pioneers' Historical Society, Tucson.

1749 Entrada a la nación de los yumas gentiles. . . . Tubutama [Sonora], January 15, 1750. MS in Arizona Pioneers' Historical Society, Tucson.

1750 Una relación. . . . sobre su entrada a las naciones gentiles confinantes de los Rios Gila y Colorado. .. . Tubutama [Sonora], December. Archivo Franciscano, Provincias Internas, Californias, Carpeta 40/68. MS in Biblioteca Nacional, México.

SEDELMAYR, JACOBO, GASPAR STIGER,

THOMAS TELLO, AND JUAN NENTUIG

1751 [Letter] to "Vuestra Reverencia." Tubutama [Sonora], June 25. MS in Arizona Pioneers' Historical Society, Tucson.

SPIER, LESLIE

1933 Yuman Tribes of the Gila River. Chicago: University of Chicago Press.

TYLER, DANIEL

1881 A Concise History of the Mormon Battalion in the Mexican War, 1846-47. Salt Lake City, Utah.

\section{U.S. NATIONAL ARCHIVES}

n.d. Record Group 75, Department of the Interior.

VELARDE, LUIS - See Manje

\section{ZARATE SALMERÓN, GERÓNIMO DE}

1856 Relaciones de . . Nuevo Mexico . . 1538 . . . 1626. Documentos para la historia de México, 3:3:30-38. México.

\section{ZÚÑIGA, IGNACIO}

1948 Rápida ojeada al estado de Sonora, territorios de California, y Arizona, año de 1835. México: Vargas Rea. Biblioteca Aportación Histórica, $2 \mathrm{~d}$ serie. 